$1-1-1992$

\title{
Nutrient fluxes for two small watersheds : seven- year results from the West Virginia University forest
}

Ray R. Hicks

Follow this and additional works at: https://researchrepository.wvu.edu/ wv_agricultural_and_forestry_experiment_station_bulletins

\section{Digital Commons Citation}

Hicks, Ray R., "Nutrient fluxes for two small watersheds : seven-year results from the West Virginia University forest" (1992). West Virginia Agricultural and Forestry Experiment Station Bulletins. 707.

https://researchrepository.wvu.edu/wv_agricultural_and_forestry_experiment_station_bulletins/600 @ WVU. It has been accepted for inclusion in West Virginia Agricultural and Forestry Experiment Station Bulletins by an authorized administrator of The Research Repository @ WVU. For more information, please contact ian.harmon@mail.wvu.edu. 


\section{Nutrient Fluxes for Two Small}

Watersheds: Seven-Year Results from the West Virginia University Forest
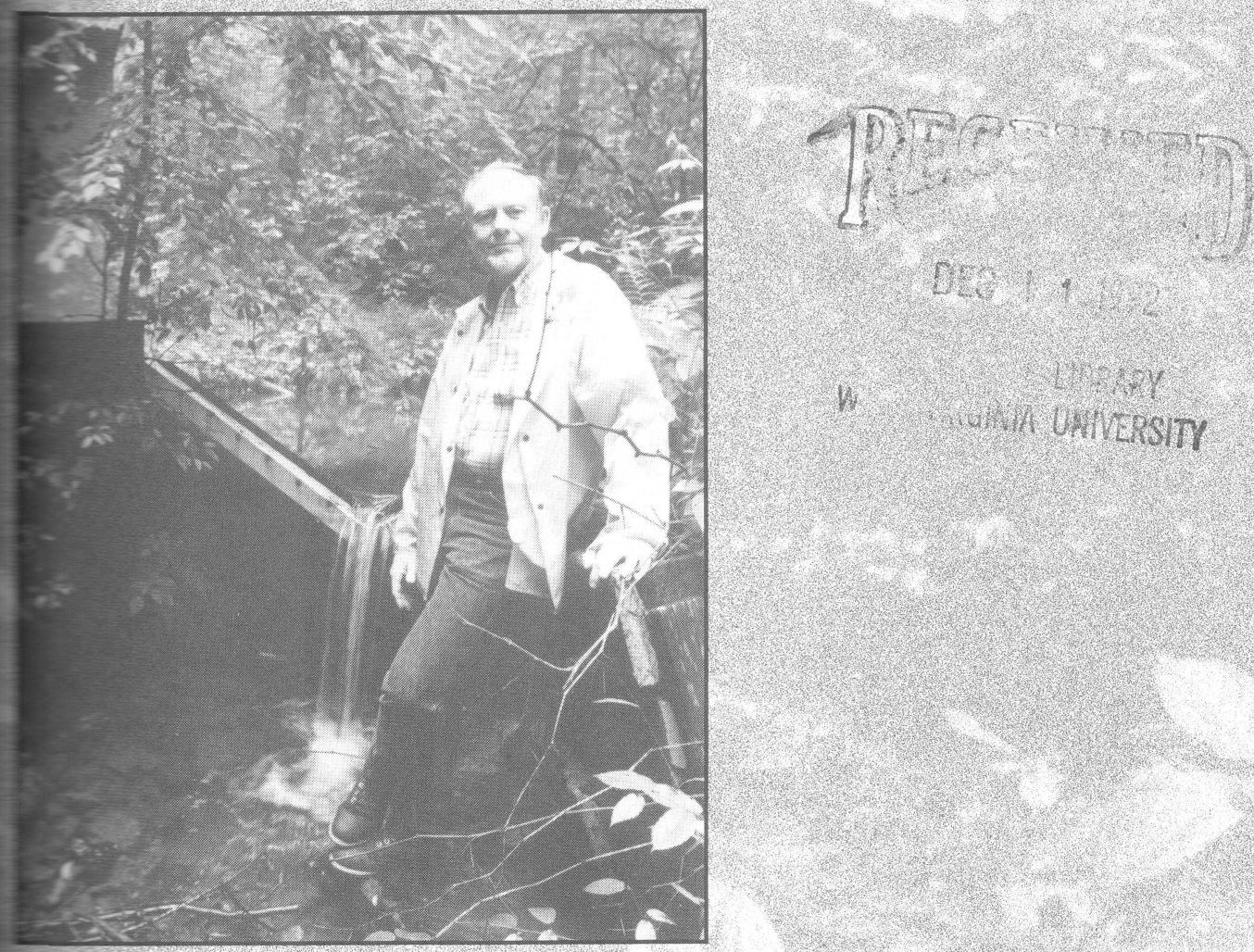

1)

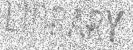

MUIV UI UWVRSTT

Bulletin 707

November 1992

Agricultural and Forestry Experiment Station

West Virginia University 


\section{Authors}

Ray R. Hicks, Jr., is professor of forestry, Darlene Mudrick is a research assistant and Edwin Townsend is professor of statistics, all in the College of Agriculture and Forestry, West Virginia University.

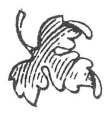

Acknowledgments

The efforts of the following graduate and undergraduate students to this project are gratefully acknowledged: M.W. Michel, P. Sallese, J. Coates, D. Irias, C. Velasquez, H. Davis (Newmarker), J. Porter. Technical assistance of D. Fosbroke and J. Flesher is acknowledged as well as laboratory work supervised by L. Nice. We also gratefully acknowledge the financial support of McIntire-Stennis (CSRS).

West Virginia University Agricultural and Forestry Experiment Station

College of Agriculture and Forestry

Robert H. Maxwell, Director

Morgantown 


\title{
Nutrient Fluxes for Two Small Watersheds: Seven-Year Results from the West Virginia University Forest
}

\author{
Ray R. Hicks, Jr., Darlene Mudrick and \\ Edwin Townsend
}

\section{Introduction}

The cycling of minerals is one of the most important processes occurring in forest ecosystems. A number of recent studies have used the small watershed approach to develop a mineral nutrient budget where substance output from streamflow is subtracted from precipitation input to determine the net gain or loss of elements to the system (Bormann and Likens 1979, Henderson and others 1978, Peterson and Rolfe 1982a). A similar study of mineral cycling has been under way at the West Virginia University (WVU) Forest near Morgantown.

The data reported here document seven years of continuous study of precipitation input and stream output from two small forested watersheds at the Forest. The two watersheds, although spatially proximal, represent extremes in several attributes. One (WS1) was on a north-facing aspect with a high-quality site for tree growth that supported a yellow-poplar, red oak and white oak cover type. The other watershed (WS2) was on a southwest slope with a relatively poor growing site that supported a chestnut oak forest type. Sallese and others (1982) and Michel (1984) reported earlier results on the two watersheds suggesting that stream water from WS1 contained higher concentrations of $\mathrm{Ca}^{+2}, \mathrm{Mg}^{+2}$ and $\mathrm{K}^{+}$than WS2 and had a higher capacity to buffer the precipitation, which had an average $\mathrm{pH}$ of about 4.0. Frank (1981) conducted a comprehensive analysis of the soils of the two watersheds. His findings indicated that soils in WS1 had higher amounts of $\mathrm{Ca}^{+2}$, $\mathrm{Mg}^{+2}, \mathrm{PO}_{4}^{-3}$ and $\mathrm{K}^{+}$than those of WS2. WS2 had lower soil $\mathrm{pH}$ and higher levels of extractable $\mathrm{Fe}$ and $\mathrm{Mn}$. The soils of both watersheds were classified as the DeKalb series (Patton and others 1959). Since the underlying geology of the two watersheds was similar, Hicks and Frank (1984) speculated that the factors causing the observed differences in the two watersheds were biological and related to processes such as litter chemistry, litter decomposition rates and nutrient uptake. 
The process of nutrient cycling has been the subject of study in many different ecosystems. For example, Henderson and others (1978) contrasted nutrient cycling in the Cascade Mountains of Oregon with that of southern Appalachian watersheds in North Carolina and eastern Tennessee. They found that bedrock composition had an important effect on cation outputs. They also discussed the important differences between hardwood ecosystems (Appalachians watersheds) and conifer ecosystems (Cascades). In spite of their differences, all three ecosystems were found to be effective in conserving and retaining elements through nutrient cycling. At the Hubbard Brook Forest in New Hampshire's White Mountains, Vitouseck (1977) reported that stream element concentrations in this northern hardwood ecosystem were regulated by several processes, including precipitation chemistry, evapotranspiration, rock weathering and plant litter accumulation.

The role of atmospheric input to the nutrient cycle has been discussed by several authors. Peterson and Rolfe (1982) studied floodplain and upland forests in central Illinois and reported that the contribution of nutrients to the forest floor from throughfall was relatively small compared to input from decomposing leaf litter. However, the elemental input from precipitation and liquid throughfall are in ionic form and readily available for plant uptake. Likens and others (1976) found that precipitation chemistry was an important component of nutrient cycling in the Hubbard Brook Experimental Forest in New Hampshire. They also found that the $\mathrm{H}^{+}$and $\mathrm{NO}_{3}{ }^{-}$concentrations in precipitation falling on the Hubbard Brook Forest had increased 1.4-fold over a 10-year period. Atmospheric input of $\mathrm{N}$ was also found to have a significant impact on the nitrogen chemistry of a northeastern Tennessee stream. The magnitude of that impact was dependent upon season and other factors (Nuckols and Moore 1982). Season was also found to be important in the amounts of elements dissolved in precipitation in a Mississippi study (Lockaby 1986). In a tropical ecosystem in Venezuela, precipitation pattern was the primary factor controlling soil water chemistry (Grimm and Fassbender 1981).

The geology of an ecosystem is an important factor governing the net chemical export from watersheds. Rochelle and others (1989) found geology to be a primary factor in determining how watersheds in the northeastern United States responded to acid deposition. The geology of our study area is discussed in detail by Hare (1957). In general, the bedrock is part of the Upper Connequenescing sandstones of the Pottsville series. The soils formed from these parent materials are often stony and relatively acidic with a pH average of about 4.5 .

A number of investigators have found that biological factors have an important bearing on the biogeochemistry of forested watersheds. Miller and others (1990) concluded that differences in catchment water chemistry in Great Britain were primarily due to vegetational or soil induced processes. 
Litter type and decomposition rates are important factors governing stream chemistry. Dwyer and Merriam (1981) investigated the effect of topographic heterogeneity on litter decomposition. Similarly, Welbourne and others (1981) found that soil chemistry was significantly correlated with litter input. Other investigators have found that plant species composition and forest cover has an important impact on mineral cycling in forested watersheds (Peterson and Rolfe 1982; Swank and Douglass 1977; Mahendrappa 1989; Sokolov 1983; Verry and Timmons 1982).

An important function of forested ecosystems is the ability to buffer acidic deposition. Mahendrappa (1986) found that forests of certain hardwood species had a greater ability to neutralize acidic rainwater than did coniferous forests in New Brunswick, Canada. Similarly, Foster (1985) found that rainwater with a seasonal average $\mathrm{pH}$ of 4.4 was partially neutralized by interaction with the canopy of a Canadian maple-birch forest. Miller (1984) attributed the alteration of $\mathrm{pH}$ in forest canopies to the hydrogen ion exchange with base cations that occurs on leaf surfaces.

Nutrient cycling is a highly seasonal process regulated by seasonal variations in biotic processes (tree growth, physiological functioning, leaf fall) and climatic processes (temperature, precipitation, solar radiation). Peterson and Rolfe (1985) found statistically significant temporal differences in the cycling of several nutrients in a floodplain forest in central Illinois. Periods of unusual climatic events such as drought can alter the nutrient cycling response of forested watersheds. Settergren and others (1978) reported that during a period of lower-than-normal precipitation, net gain for $\mathrm{K}^{+}, \mathrm{Na}^{+}$and $\mathrm{Ca}^{+2}$ occurred in an Ozark watershed in Missouri, whereas most other studies in the eastern United States show export for these elements.

The two watersheds at the WVU Forest occur on essentially the same geologic formations and are subjected to similar precipitation (both quantitatively and qualitatively). It seems logical that the difference in response of the two watersheds is related to biological factors such as forest cover and/or leaf litter dynamics. An additional possibility is the effect of energy flux that is associated with aspect. Frank (1981) did an in-depth soil analysis of the entire area, including the two watersheds, and found that soil nutrient concentrations were associated with aspect. Higher soil values of $\mathrm{Mn}$ and $\mathrm{K}$ were associated with northeast slopes, while higher values of $\mathrm{Fe}$ and $\mathrm{H}$ were associated with southwest slopes. In another study, Sallese and others (1982) placed lysimeter tubes at 6 locations within each watershed and measured soil water chemistry during the 1981 growing season. Their results showed that all elements demonstrated seasonal changes. For $\mathrm{Ca}^{+2}$ and $\mathrm{Mg}^{+2}$, highest values occurred during the mid-summer period with lowest values in the spring (May-June). These relationships were reversed for $\mathrm{K}^{+}$and $\mathrm{Na}^{+}$. 
Generally, element concentration was higher in soil water from WS1 that from WS2, especially for $\mathrm{K}^{+}$and $\mathrm{Mg}^{+2}$.

Peterson and Rolfe (1982a, 1982b) also found species-specific responses of watersheds from upland and bottomland forest types in central Illinois They further concluded that the annual mineral contribution of precipitatior was small compared to that from leaf litter, with the exception of potassium Johnson and others (1985) studied the cycling of $\mathrm{K}^{+}, \mathrm{Ca}^{+2}$ and $\mathrm{Mg}^{+2}$ anc compared the fluxes of elements between a chestnut oak (Quercus prinus L.), and a yellow-poplar (Liriodendron tulipifera L.) cover type in eastern Ten. nessee. This study bears several similarities to ours, both in the species occupying the sites and in the general response patterns, where the yellowpoplar forest exported greater amounts of cations than the chestnut oak forest. The corroboration of our previously reported results by Johnson and others provides still more motivation to seek answers about why these differences occur.

\section{Methods}

Two small watersheds were selected for study at the West Virginia University (WVU) Forest in Preston County, W.Va. One 40-acre watershed, located on a northeast-facing slope, was dominated by a yellow-poplar forest with components of northern red oak (Quercus rubra), black cherry (Prunus serotina) and red maple (Acer nubrum). The other, approximately 75-acre, watershed was situated on a southwest-facing aspect with chestnut oak (Quercus prinus) and northern red oak as principal cover species (Figure 1). WS1, on the northeast slope, possessed the best growing sites. Although they are essentially the same age, trees were noticeably larger on WS1 than on WS2.

In August 1984, a weir was constructed on WS1 using the design of Whipkey (1961). A $120^{\circ} \mathrm{V}$-notch control section was established, and an event recorder was installed. The weir was rated by directly measuring the amounts of water produced over a given time interval at different stages of water over the weir (Michel 1984). In addition to flow measurements from the weir, water samples were collected weekly at three stations beginning in October 1983, before the weir was constructed. One of these collections was taken using a precipitation sampler and one each from the streams flowing from WS1 and WS2. These weekly collections were taken to a laboratory and analyzed for $\mathrm{Ca}^{+2}, \mathrm{~K}^{+}, \mathrm{Mg}^{+2}, \mathrm{Na}^{+}, \mathrm{PO}_{4}{ }^{-3}, \mathrm{NO}_{3}^{-}$and $\mathrm{SO}_{4}{ }^{-2}$. Not all elements were measured in all years. The data for streamflow were processed at the Northeast Forest Experiment Station Laboratory, USDA Forest Service, in Parsons, W.Va., to produce total streamflow per day and per month. Streamflow for WS2, which was not equipped with a weir, was predicted using a regression procedure and monthly precipitation to find 
monthly streamflow (Nik 1981). We used the same technique to estimate streamflow for WS1 for months that were missing streamflow data due to equipment failure or other reasons.

The element concentrations (milligrams per liter) were averaged per month and then multiplied by the number of liters flowing from the watershed per month to obtain monthly nutrient export. We multiplied the monthly rainwater volume (obtained from the nearby Coopers Rock weather station) by the average concentration of elements in the water to obtain monthly nutrient import.

\section{Results}

In our watersheds, outputs exceeded inputs for $\mathrm{Ca}^{+2}$ and $\mathrm{Mg}^{+2}$ (Table 1, Figure 2); thus, when expressed as a annual nutrient budget (input minus output) they were negative. Our results for $\mathrm{NO}_{3}{ }^{-}$are corroborated by results from the northern hardwoods (Bormann and Likens 1979). Negative budgets are typical for substances other than $\mathrm{NO}_{3}{ }^{-}$studied in forested watersheds in the eastern United States (Johnson and Swank 1973). One way of comparing the mean input/output data is by examining the proportion that output (from streamflow) is of input from precipitation. The substances monitored were ranked in this regard as follows: $\mathrm{NO}_{3}^{-}(170 \%), \mathrm{PO}_{4}^{-3}(150 \%), \mathrm{Na}^{+}(93 \%)$, $\mathrm{K}^{+}(92 \%), \mathrm{Ca}^{+2}(52 \%)$ and $\mathrm{Mg}^{+2}(12 \%)$. For substances such as $\mathrm{Mg}^{+2}$ and $\mathrm{Ca}^{+2}$, where input is less than output, the additional output probably came from internal sources within the watershed, such as rock weathering.

An interesting finding is the seasonal distribution of inputs and outputs. In Table 1, it can be seen that substance inputs from precipitation generally displayed little or no seasonal pattern. Peak outputs for all substances occurred in the months of November through March (Figures 3-10). In part, this can be explained by the higher streamflows that occurred during this period (Figure 11). Certainly the low exports that occurred in August and September can be attributed to low streamflow during these months. The physiological activity of plants growing in the watersheds has an important influence on these relationships as well. Trees are generally dormant from October through April, and increased substance output during that period may reflect the lack of plant uptake during the dormant season. Certain substances $\left(\mathrm{Na}^{+}, \mathrm{K}^{+}\right.$and $\left.\mathrm{PO}_{4}{ }^{-3}\right)$ showed a lower tendency to be seasonally cyclical than others $\left(\mathrm{Ca}^{+2}, \mathrm{Mg}^{+2}\right.$ and $\left.\mathrm{NO}_{3}{ }^{-}\right)$. For $\mathrm{Na}^{+}$, the explanation probably lies in the fact that it is not an element required in plant physiological processes. $\mathrm{Na}^{+}$is not selectively taken up or stored in plant tissues. It would be less subject to the effects of plant uptake than required elements. For $\mathrm{K}^{+}$and $\mathrm{PO}_{4}^{-3}$, the situation is not as clear. The peak export of $\mathrm{K}$ apparently occurs in November for both watersheds. This might be a function of release of $\mathrm{K}^{+}$from leaf litter associated with decomposition of, and 
leaching from, recently fallen leaves. $\mathrm{Ca}^{+2}, \mathrm{Mg}^{+2}$ and nitrate cycles generally follow patterns associated with the hydrologic and physiological dynamics of the forest system. One factor that seems to drive the nutrient input/output process is the annual hydrologic cycle. There was a slight seasonal pattern observed for precipitation volume with the highest monthly precipitation occurring during the spring/summer season and the lowest through the winter (Figure 11). The variation in precipitation was relatively small, however, compared to that of streamflow. The streamflow was lowest during the summer season, reflecting the transpirational impact of the forest on streamflow. Conversely, the highest flows occurred during the winter months when trees were dormant. The monthly mean outputs from the watersheds reflect the differences in streamflow volume for most elements (Tables 2-7). This effect can also be seen in Figures 3-10. The seasonal volume effect may be partially offset by increased concentration of certain elements (e.g., sodium) during the low flow periods of late summer.

Typically, for all substances, the output from WS1 exceeded that of WS2 (Table 1-7, Figures 3-8). This is consistent with the results of Johnson and others (1985). They found that a yellow-poplar ecosystem produced higher outputs of substances than a chestnut oak forest, which is analogous to our watersheds 1 and 2. These results are also consistent with earlier reports from watersheds 1 and 2 (Sallese and others 1982).

Tables 2-7 illustrate the seasonal and year-to-year fluctuations in nutrient inputs and outputs. Although the annual sums seem to indicate yearly variability in substance export, these results should be viewed with caution since three different chemistry labs conducted the analyses over the years. Although they all stated that EPA standard tests were used, noticeable and consistent changes always seemed to accompany changes in labs.

The differential $\mathrm{pH}$ response of the two watersheds is another aspect that deserves attention. The precipitation falling on our watersheds was generally acidic, with an average $\mathrm{pH}$ of approximately 3.9 (Figure 12). There was little noticeable seasonal trend to precipitation $\mathrm{pH}$, although the highest average monthly value (4.3) was for the month of January and the lowest monthly value (3.6) was for June. There was little correlation between the streamwater $\mathrm{pH}$ and that of precipitation. The Pearson correlation coefficients for WS1 and WS2 were 0.14 and 0.18 , respectively. The mean annual stream water $\mathrm{pH}$ for WS1 was approximately 5.1, compared to an annual average of 4.4 for WS2. Thus precipitation contains a concentration of $\mathrm{H}^{+}$ that is about 3.75 times greater than streamwater from WS2 and 18.75 times greater than in WS1. Both WS1 and WS2 did demonstrate a seasonal pH response, although it seemed more prominent in WS1 (Figure 12). Highest $\mathrm{pH}$ levels in both watersheds occurred during the spring and summer months. There was a high correlation between the monthly $\mathrm{pH}$ values of WS1 and WS2 $(r=0.90)$. 


\section{Discussion and Conclusions}

After seven years of study on two small watersheds at the WVU Forest, certain conclusions are becoming clear. First, the nutrient input/output budgets for calcium and magnesium are negative, indicating that our watersheds are exporting more of these substances than they are importing from precipitation. This is consistent with the findings of other studies in the eastern United States. We found that nitrate and phosphate had positive budgets and sodium and potassium were about balanced. We found a pronounced seasonal output response, more so for some elements than for others. In great measure, this reflects the seasonal hydrologic pattern of the watersheds rather than precipitation volume or chemistry, although some of the seasonality may be related to cyclical biological phenomena and/or the proportion of ground water to surface water present in streams at a given time.

We found WS1 was consistently higher in its output of elements compared to WS2. This seems to relate to the difference in vegetative cover on the two watersheds rather than to geologic or climatic phenomena. Perhaps the leaf litter produced by the species growing on WS1 was more readily decomposed, allowing more nutrient exportation from that site than from WS2.

Average precipitation $\mathrm{pH}$ was very low (3.9 annual average), and streamwater from WS1 had a much higher $\mathrm{pH}$ than that from WS2. In general, the pH of streamwater in WS1 was a whole unit higher than that of the incoming precipitation, whereas streamflow from WS2 was only slightly higher than the precipitation $\mathrm{pH}$.

A major conclusion of this work is that the forest exerts a strong influence on the biogeochemistry of the watersheds. For example, the seasonal nature of substance output can, in large measure, be explained by the seasonal cycle in stream hydrology, which in turn is related to the effect of transpiration on streamflow. The consistent differences in nutrient output and $\mathrm{pH}$ between WS1 and WS 2 are most logically explained by the difference in vegetative cover (yellow-poplar, maple, cherry on WS1 versus oaks on WS2).

It appears that the good growing conditions on WS1 are conducive to more rapid nutrient cycling and even, perhaps, to greater nutrient output. Hicks and Frank (1984) found that soils on the north and northeast aspects contained higher levels of several essential elements than did soils on the south and southwest aspects. This, in combination with the input/output data reported here, suggests that mineral nutrients are more abundant and more rapidly cycled on the better growing sites than on the poor ones.

The hydrologic and nutrient cycling results reported here have significance in their own right, but these data may also serve as a baseline for 
future studies. For example, the effect of disturbances such as gypsy moth defoliation and timber harvesting on nutrient cycling and hydrology might be compared to these data that represent a relatively undisturbed condition.

\section{Literature Cited}

Bormann, F.H. and Likens, G.E. 1979. Pattern and Process in a Forested Ecosystem. Springer-Verlag. New York. 253 p.

Dwyer, L.M. and Merriam, G. 1981. Influence of topographic heterogeneity on deciduous litter decomposition. Oikos 37: 228-237.

Frank, P.S., Jr. 1981. Forest Biomass Predicted by Soil-Site Factors. Ph.D. Dissertation, West Virginia University, Morgantown, W.Va.

Grimm, V. and Fassbender, H.W. 1981. Biogeochemical cycles in a forest ecosystem of the western Andes of Venezuela. III. Hydrological cycle and chemical element transfer. Turrialba 31(2): 89-99.

Hare, C.E. 1957. Geology of Coopers Rock State Forest and Mont Chateau State Park, WV. West Virginia Geologic and Economic Survey. State Park Series Bull. No. 5.26 pp.

Henderson, G.S., Swank, W.T., Waide, J.B. and Grier, C.C. 1978. Nutrient budgets of Appalachian and Cascade region watersheds: a comparison. Forest Sci. 24(3): 385-397.

Hicks, R.R., Jr., and Frank, P.S., Jr. 1984. Relationship of aspect to soil nutrients, species importance and biomass in a forested watershed in West Virginia. Forest Ecol. and Mgt. 8: 281-291.

Johnson, D.W., Richter, D.D., Lovett, G.M. and Lindberg, S.E. 1985. The effects of atmospheric deposition on potassium, calcium and magnesium cycling in two deciduous forests. Can. J. Forest Res. 15(5): 773-782.

Likens, G.E., Bormann, F.H., Eaton, J.S., Pierce, R.S. and Johnson, N.M. 1976. Hydrogen ion input to the Hubbard Brook Experimental Forest, New Hampshire, during the last decade. Water, Air and Soil Pollution 6 (2-4): 435-445.

Lockaby, B.G. 1986. Nutrient transfer associated with precipitation in plantations of eastern cottonwood (Populus deltoides). Forest Ecol. and Mgt. 17: 13-24.

Mahendrappa, M.K. 1986. Ability of organic horizons under some eastern Canadian forests to alter the acidity of rainwater. Can. J. Forest Res. 16: 18-22. 
Mahendrappa, M.K. 1989. Impacts of forests on water chemistry. Water, Air and Soil Pollution 46 (1-4): 61-72.

Michel, M.G. 1984. Nutrient relations in a forested watershed. M.S. Thesis. West Virginia University. 79 pp.

Miller, J.D., Anderson, H.A., Ferrier, R.C., Walker, T.A.B. 1990. Comparison of hydrological budgets and detailed hydrological responses in two forested catchments. Forestry (Oxford) 63(3): 251-269.

Nik, A.R.H. 1981. Normal evaporation and discharge from an undisturbed forested catchment. M.S. Thesis. West Virginia University. 104 pp.

Nuckols, J.R. and Moore, I.D. 1982. The influence of atmospheric nitrogen influx upon the stream nitrogen profile of a relatively undisturbed forested watershed. Hydrology 57: 113-135.

Patton, B.J., Beverage, W.W. and Pohlman, G.G. 1959. Soil Survey of Preston County, West Virginia. U.S.D.A., SCS. W.Va. Agr. Exp. Sta., Series 1954, No. 3.

Peterson, D.L. and Rolfe, G.L. 1982a. Precipitation components and nutrient pathways in floodplain and upland forests of central Illinois. Forest Sci. 28(2): 321-332.

Peterson, D.L. and Rolfe, G.L. 1982b. Nutrient dynamics and decomposition of litterfall in floodplain and upland forests in central Illinois. Forest Sci. 28(4): 667-681.

Peterson, D.L. and Rolfe, G.L. 1985. Temporal variation in nutrient status of a floodplain forest soil. Forest Ecol. and Mgt. 12: 73-82.

Rochelle, B.P., Liff, C.I., Campbell, W.G., Cassell, D.L., Church, M.R. and Nusz, R.A. 1989. Regional relationships between geographic/hydrologic parameters and surface water chemistry relative to acidic deposition. $J$. Hydrology 112: 103-120.

Sallese, P.A., Coates, J.A. and Hicks, R.R., Jr. 1982. Nutrient relationships in two small West Virginia watersheds. Proc. 4th Cent. Hardwood Forest Conf., Lexington, Ky. 322-343.

Settergren, C.D., Winters, D.A., Nugent, R.M. 1978. Hydrologic nutrient cycle relations in the Ozarks. Proc. 2nd Cent. Hardwood For. Conf., LaFayette, Ind. 243-255.

Sokolov, A.A. 1983. The effect of forest on the removal of mineral elements into water courses. Lesovedenie 5: 8-14.

Swank, W.T. and Douglass, J.E. 1977. Nutrient budgets for undisturbed and 
manipulated forest ecosystems in the mountains of North Carolina. In Watershed Research in Eastern North America. A Workshop to Compare Results. Edgewater, Md.

Verry, E.S., and Timmons, D.R. 1982. Waterborne nutrient flow through an upland peatland watershed in Minnesota. Ecology 63(5): 1456-1467.

Vitouseck, D.M.1977. The regulation of element concentrations in mountain streams in the northeastern United States. Ecol. Monographs 47(1): 65-87.

Wellbourn, M.L., Stone, E.L. and Lassoie, J.P. 1981. Distribution of net litter inputs with respect to slope position and wind direction. Forest Sci. 27(4): 651-659.

Whipkey, R.Z. 1961. Plywood cutoff walls for temporary weirs. Cent. States For. Exp. Sta. Note No. 150. 2 pp. 


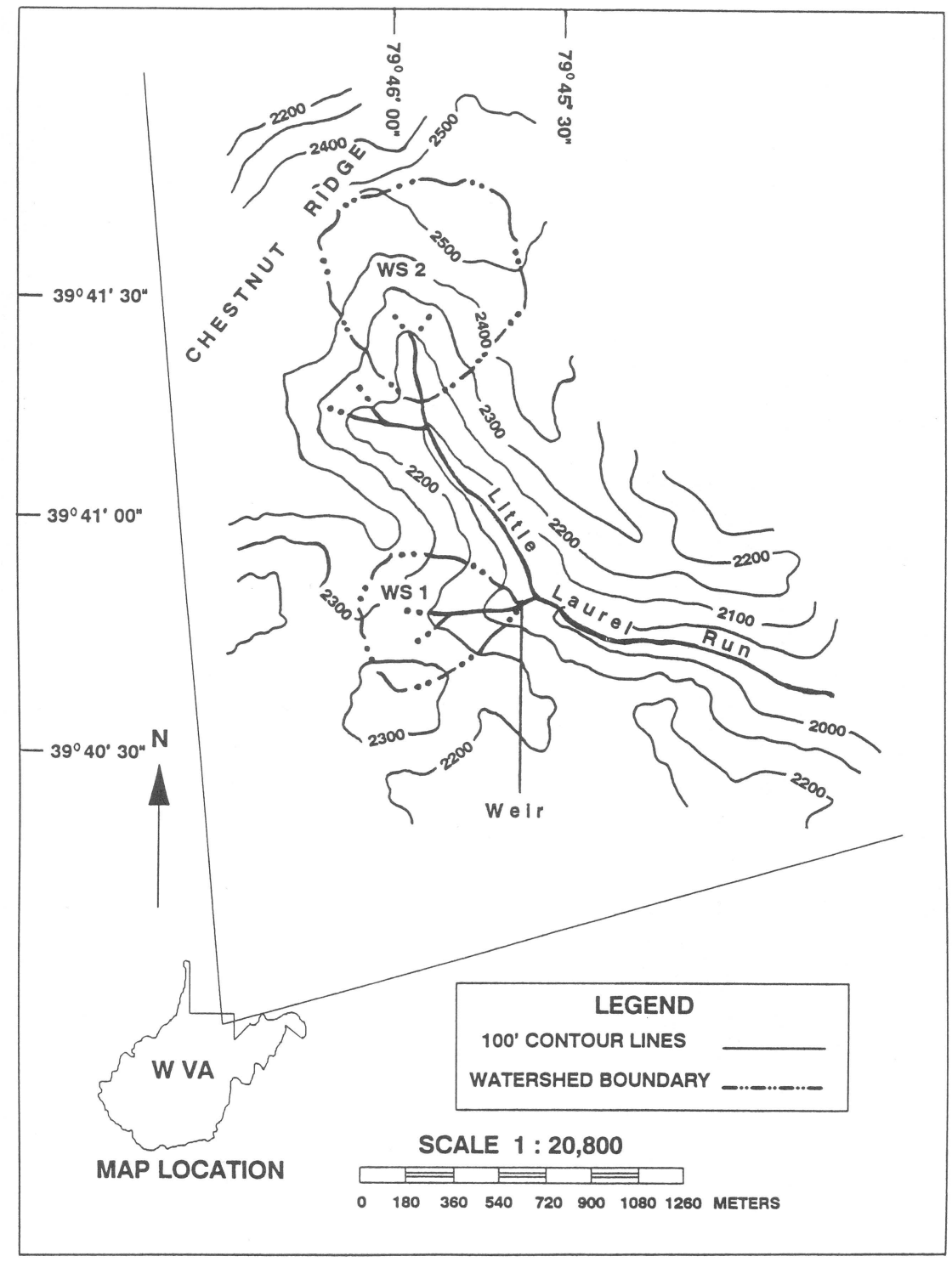

Figure 1. Location of study watersheds at the West Virginia University Forest. 


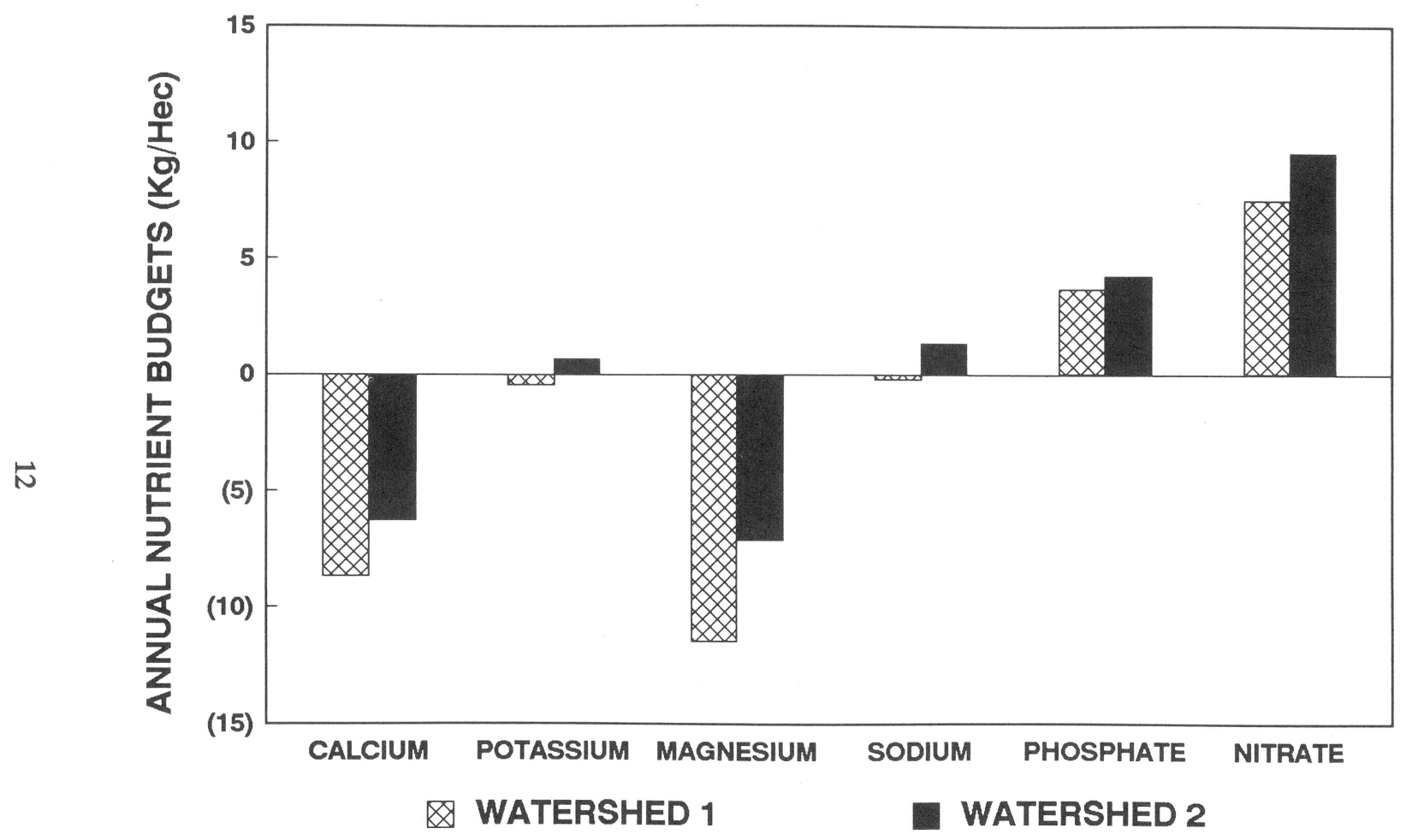

Figure 2. Average yearly nutrient budgets (inputs minus outputs) for 6 substances studied. 


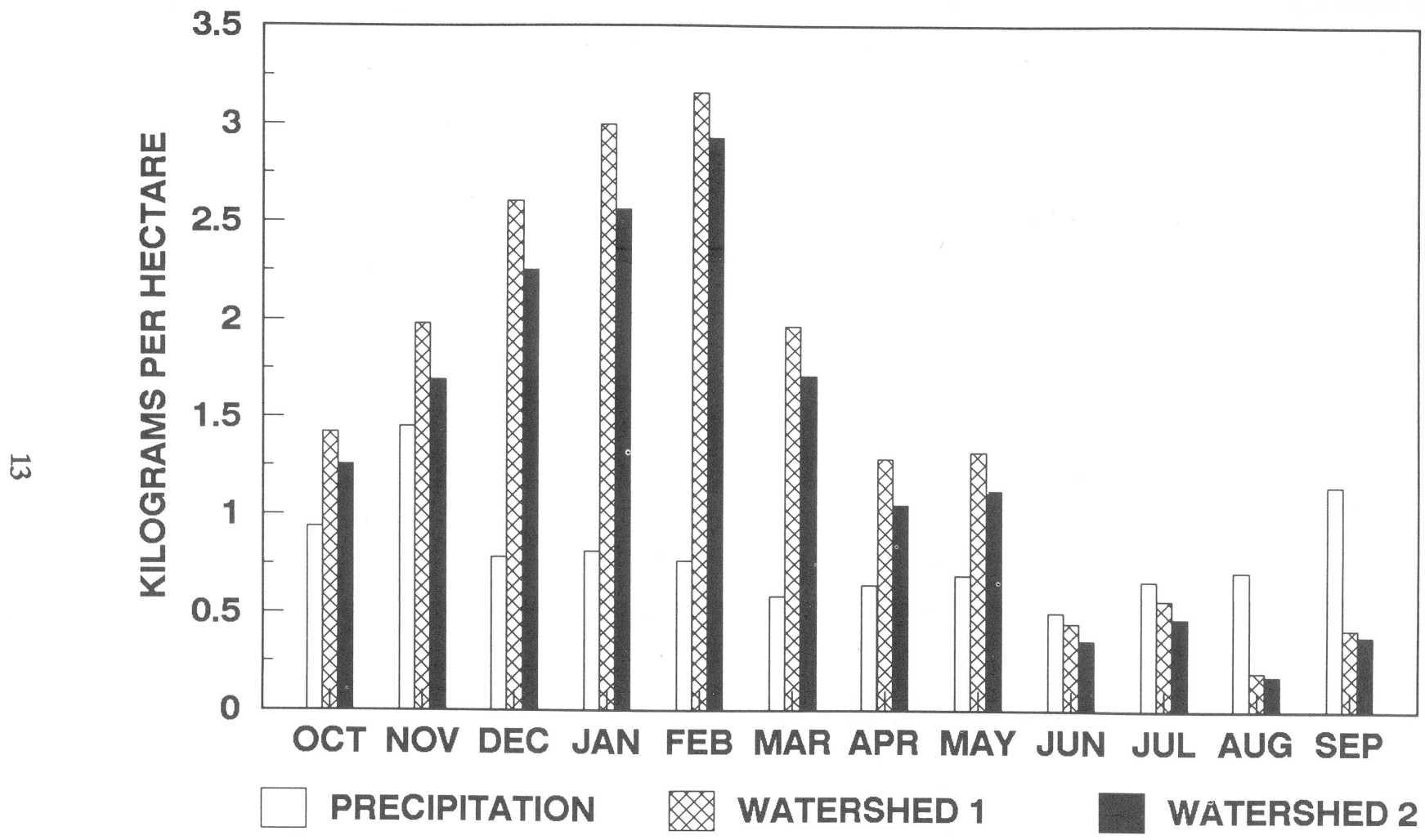

Figure 3. Monthly calcium inputs and outputs from watersheds 1 and 2. 


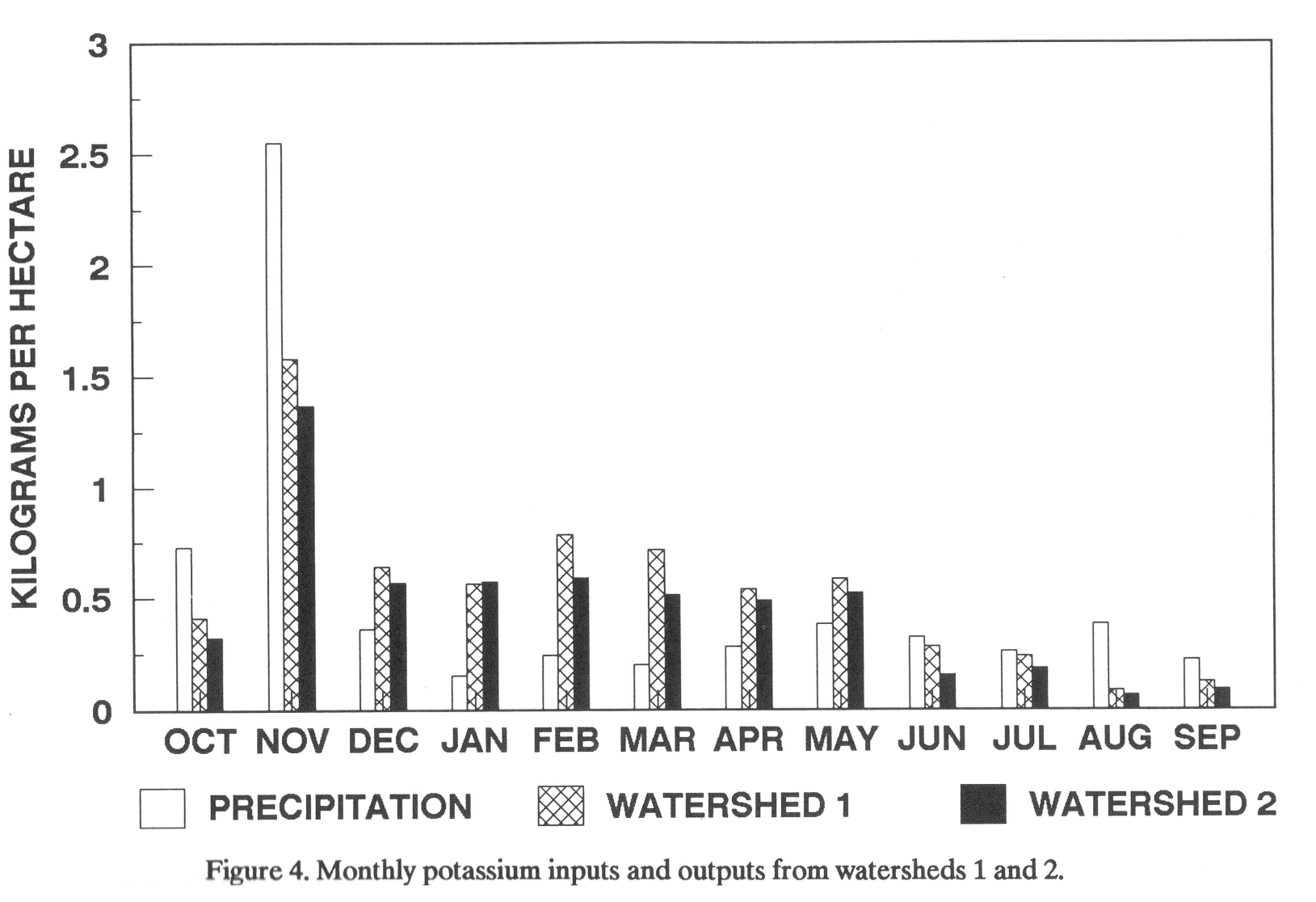



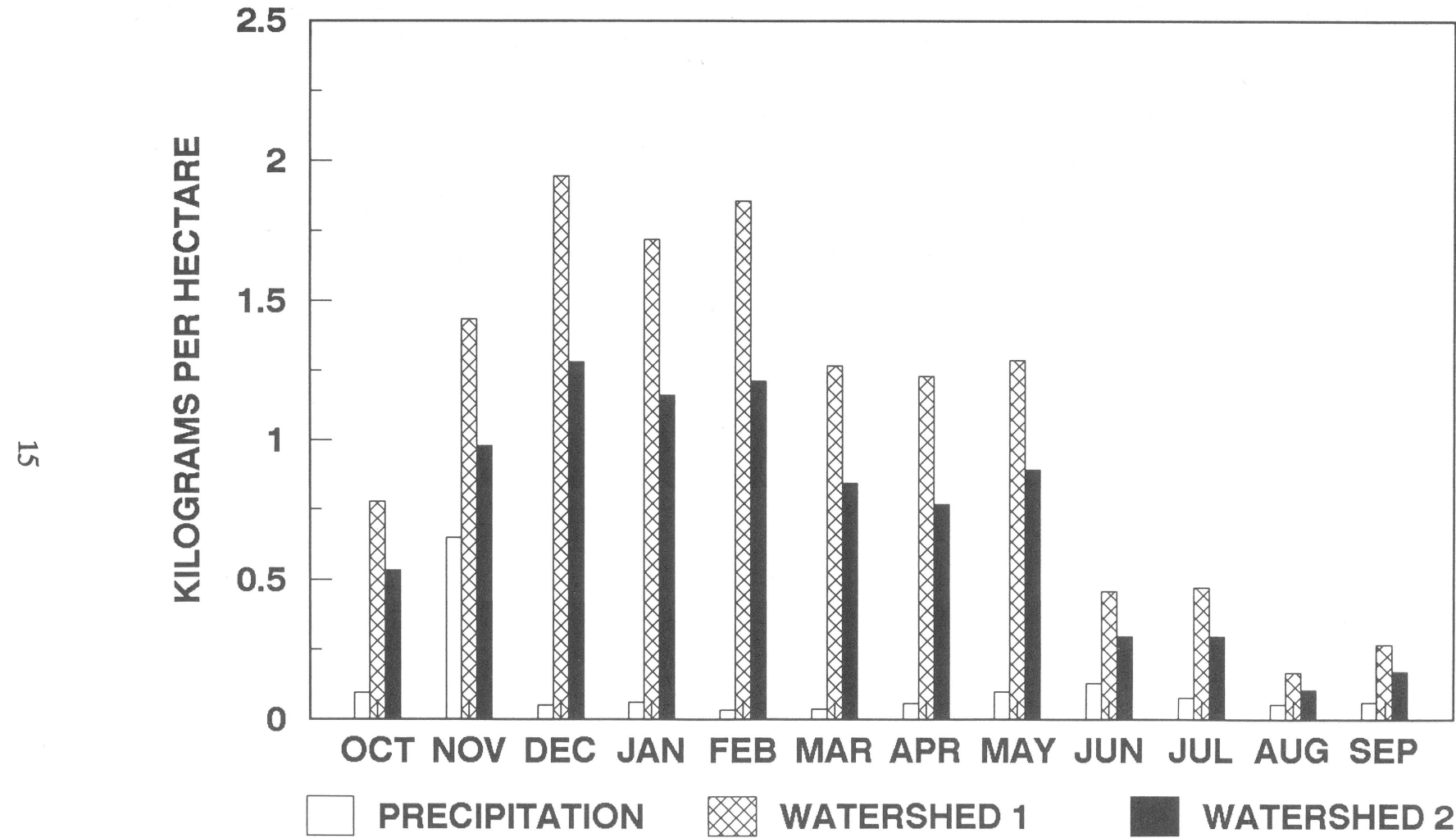

Figure 5. Monthly magnesium inputs and outputs from watersheds 1 and 2 . 


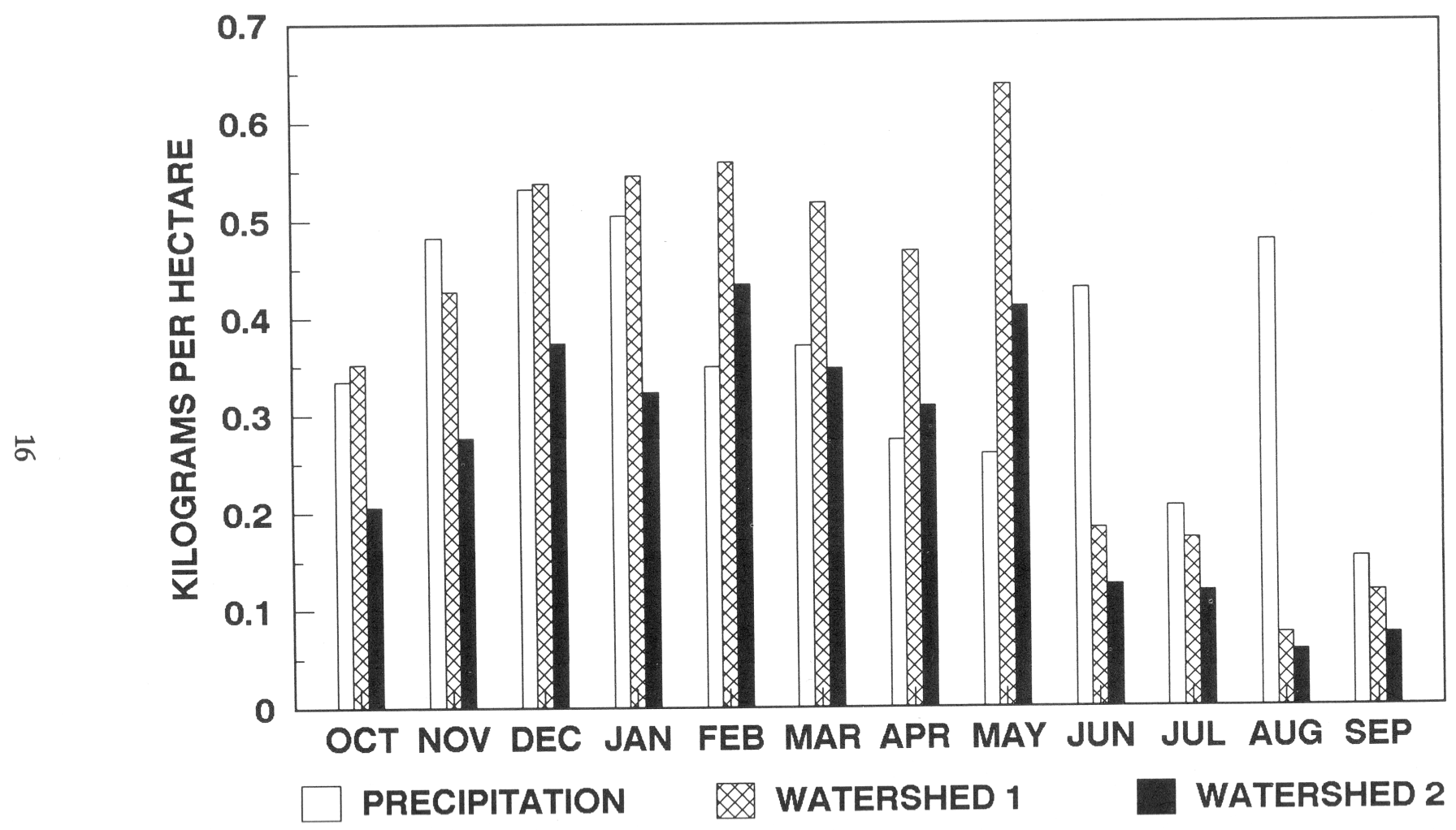

Figure 6. Monthly sodium inputs and outputs from watersheds 1 and 2. 


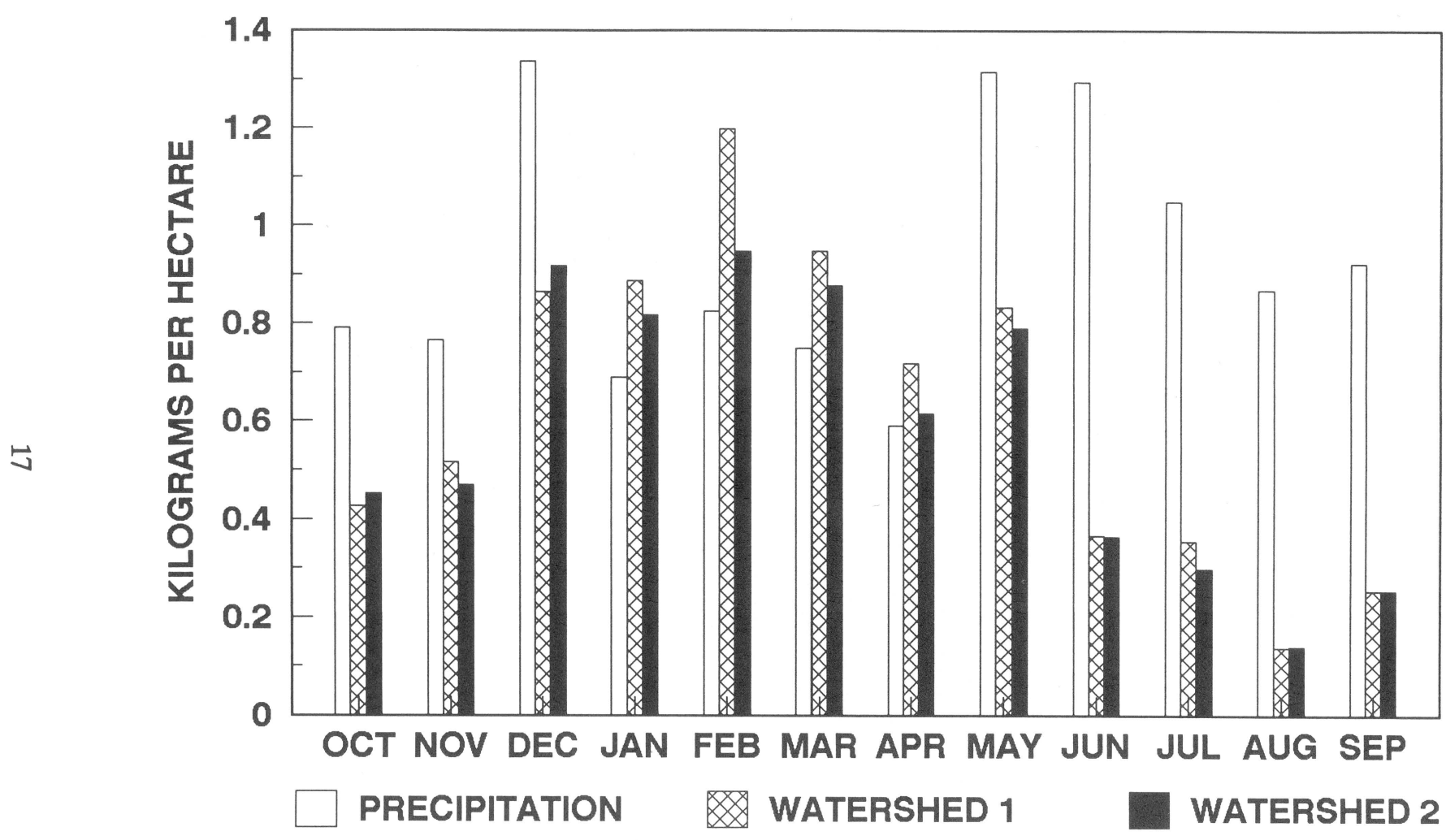

Figure 7. Monthly phosphate inputs and outputs from watersheds 1 and 2. 


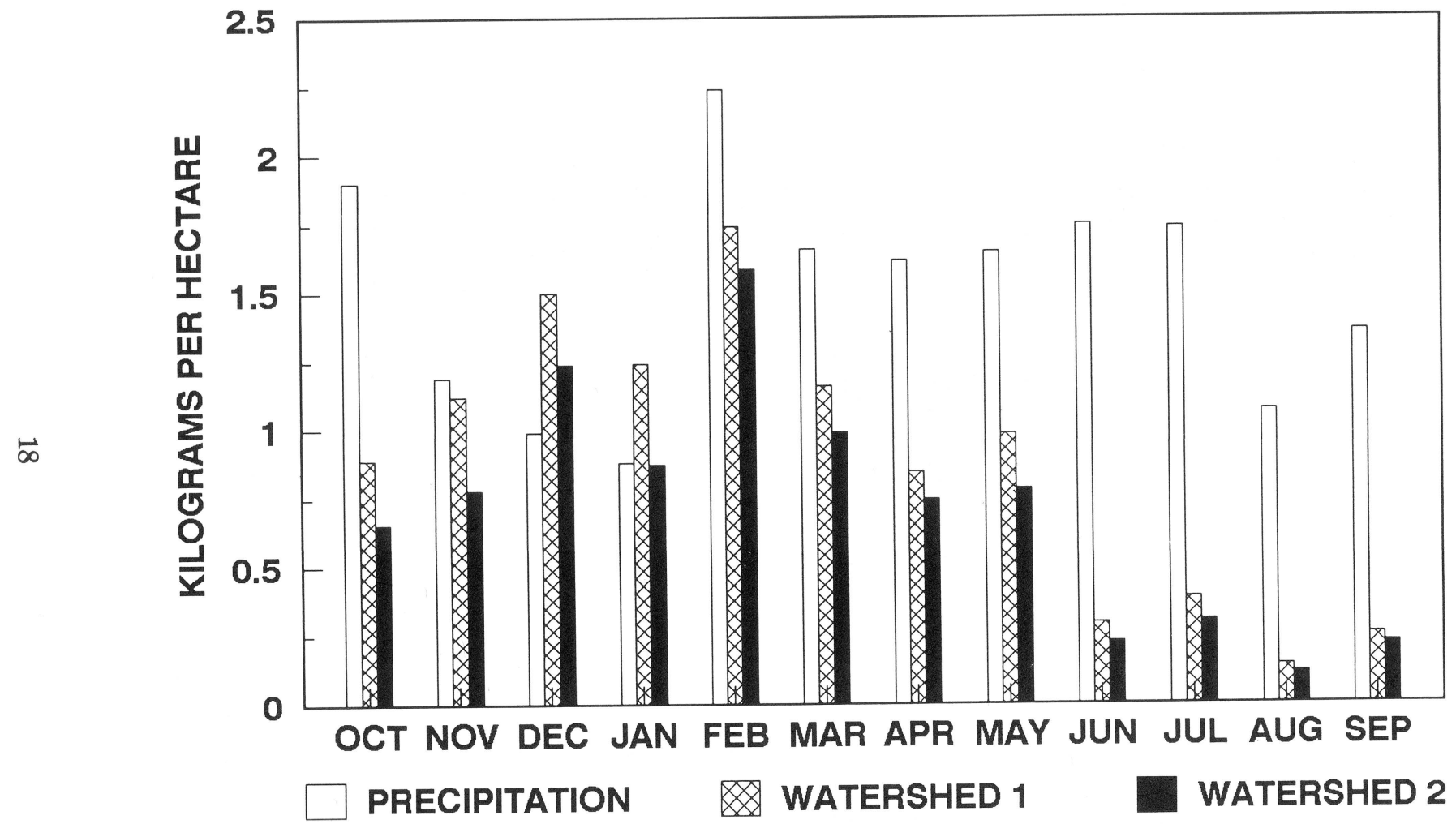

Figure 8. Monthly nitrate inputs and outputs from Watersheds 1 and 2. 


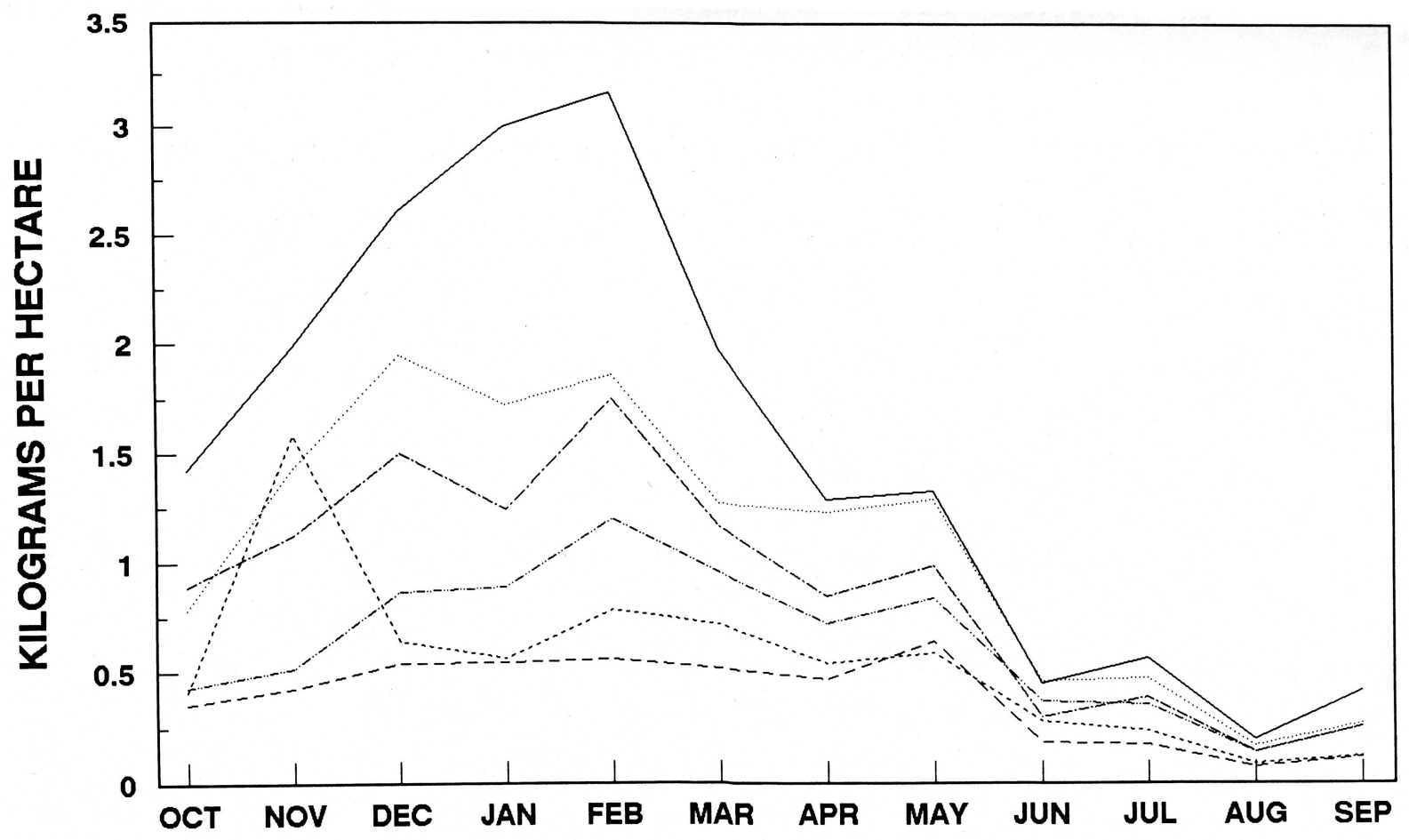

CALCIUM POTASSIUM MAGNESIUM SODIUM PHOSPHATE NITRATE

Figure 9. Mean monthly output of elements (kg/ha) from watershed 1. 


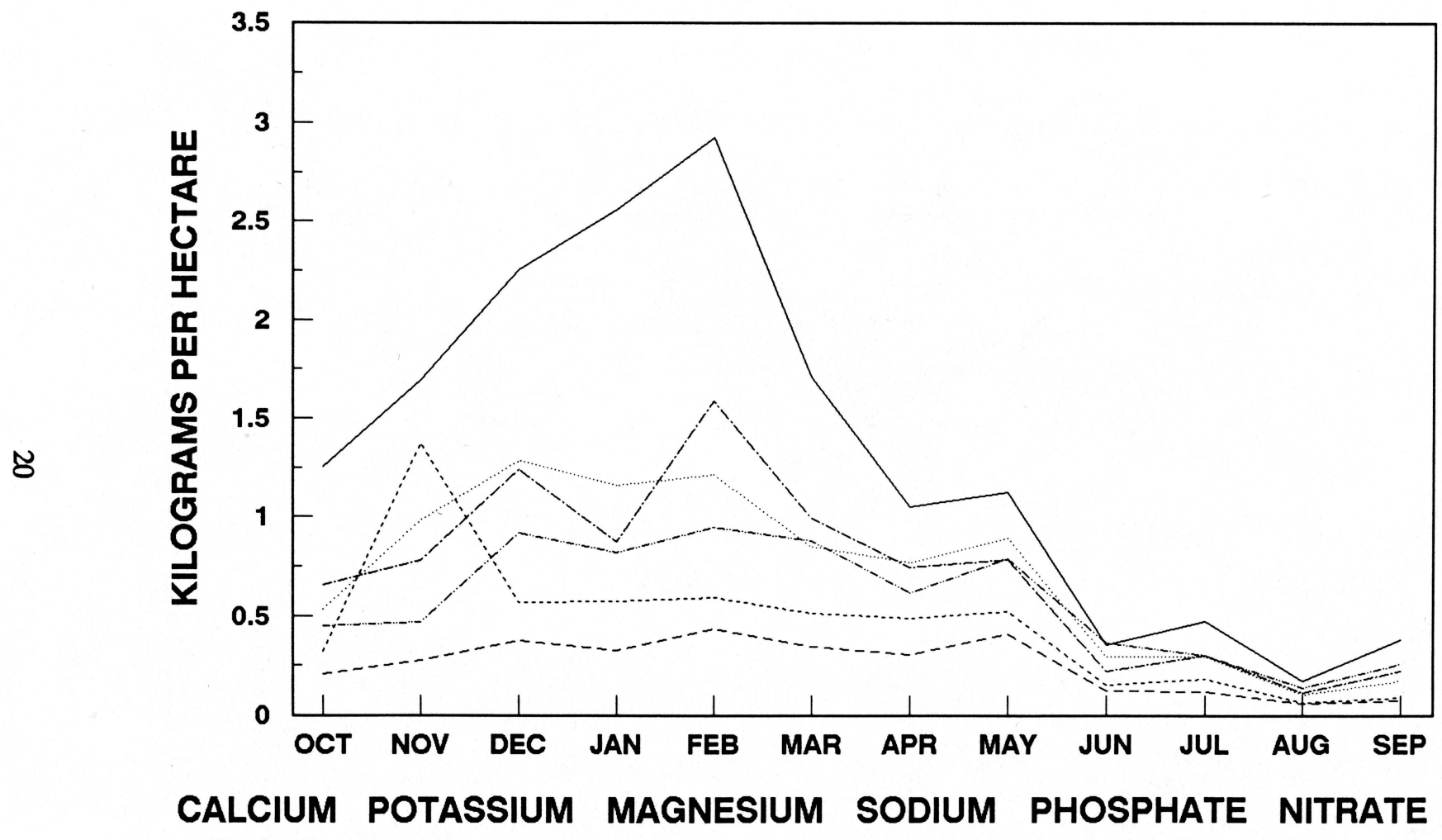

Figure 10. Mean monthly output of elements (kg/ha) from watershed 2. 


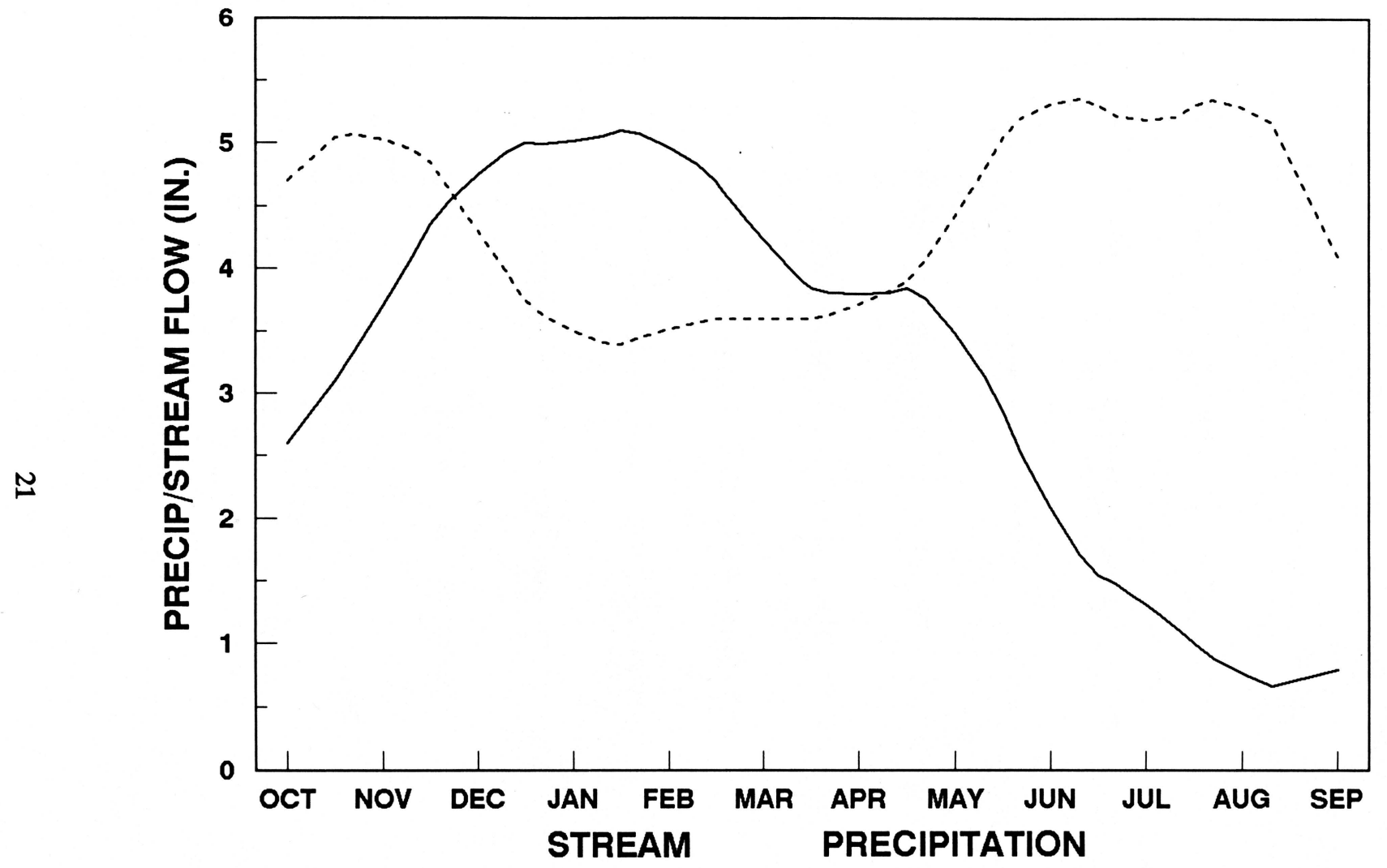

Figure 11. Hydrologic data for precipitation and watersheds 1 and 2 over the study period. 


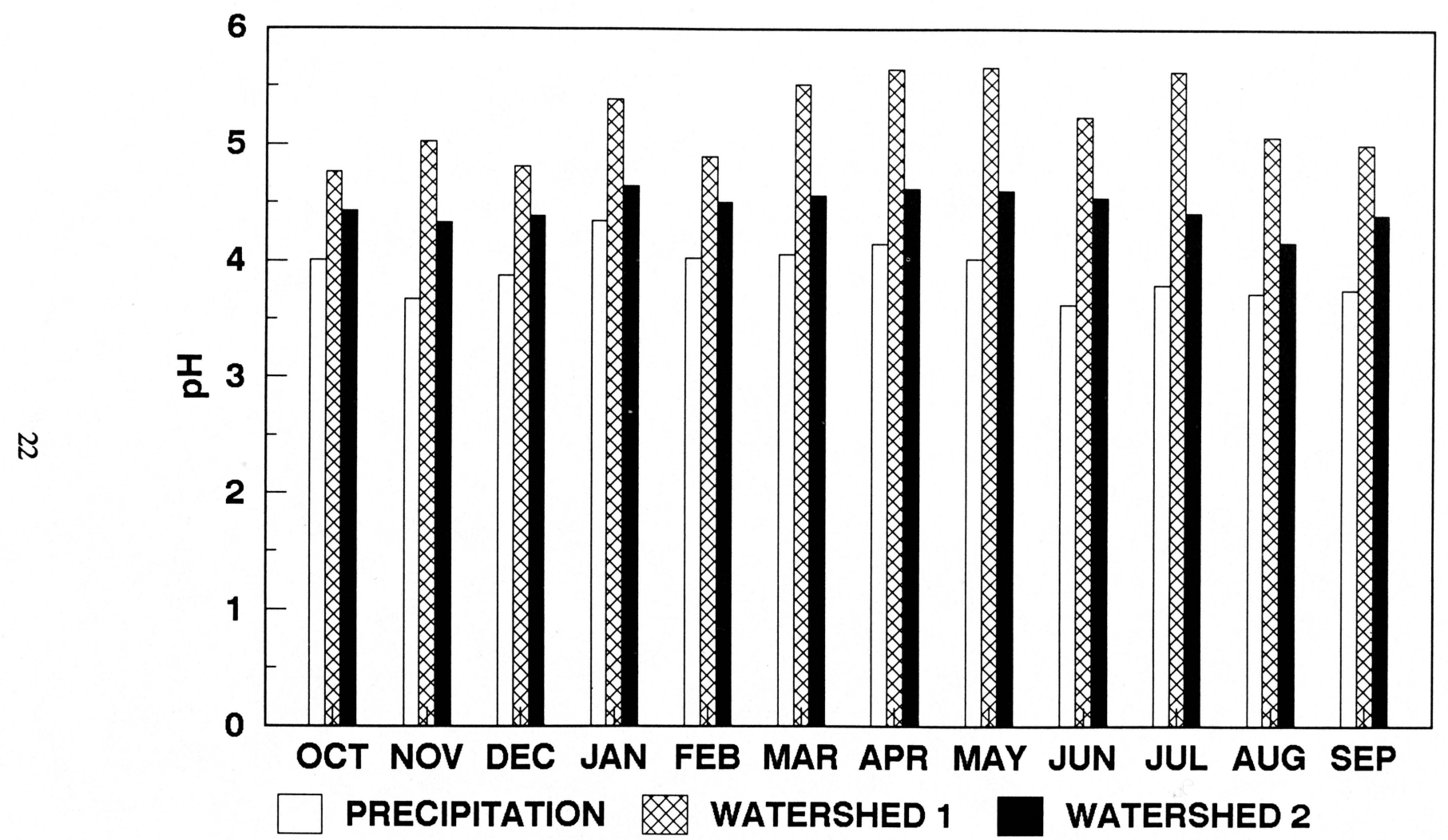

Figure 12. Monthly averages for $\mathrm{pH}$ for precipitation and watersheds 1 and 2. 
Table 1. Mean Monthly Precipitation Input and Output of Elements in Kilograms per Hectare on Watershed 1 and Watershed 2. (Data from October 25, 1983 to February 28, 1991.)

\begin{tabular}{lllllllllllllll}
\hline & OCT. & NOV. & DEC. & JAN. & FEB. & MAR & APR. & MAY & JUNE & JULY & AUG. & SEPT. & $\begin{array}{c}\text { ANNUAL } \\
\text { SUM }\end{array}$ & BUDGET \\
I-O
\end{tabular}


Table 2. Monthly Means and Annual Sums (kg/ha) for Calcium.

\begin{tabular}{|c|c|c|c|c|c|c|c|c|}
\hline & 1984 & 1985 & 1986 & 1987 & 1988 & 1989 & 1990 & $\begin{array}{l}\text { Monthly } \\
\text { Average }\end{array}$ \\
\hline $\begin{array}{l}\text { JANUARY } \\
\text { Input C1 } \\
\text { Output WS1 } \\
\text { Output WS2 }\end{array}$ & $\begin{array}{l}0.230 \\
2.557 \\
1.934\end{array}$ & $\dot{.}$ & $\begin{array}{l}1.370 \\
2.960 \\
2.292\end{array}$ & $\begin{array}{l}0.150 \\
1.211 \\
0.936\end{array}$ & $\begin{array}{l}2.580 \\
5.322 \\
5.162\end{array}$ & $\begin{array}{l}0.390 \\
3.905 \\
3.287\end{array}$ & $\begin{array}{l}0.120 \\
2.014 \\
1.735\end{array}$ & $\begin{array}{l}0.81 \\
2.99 \\
2.56\end{array}$ \\
\hline $\begin{array}{l}\text { FEBRUARY } \\
\text { Input C1 } \\
\text { Output WS1 } \\
\text { Output WS2 }\end{array}$ & $\begin{array}{l}0.320 \\
3.014 \\
2.584\end{array}$ & $\begin{array}{l}2.253 \\
.\end{array}$ & $\begin{array}{l}0.410 \\
3.949 \\
4.204\end{array}$ & $\begin{array}{l}0.070 \\
0.864 \\
0.708\end{array}$ & $\begin{array}{l}3.600 \\
4.745 \\
4.459\end{array}$ & $\begin{array}{l}0.140 \\
5.063 \\
3.703\end{array}$ & $\begin{array}{l}0.050 \\
2.221 \\
1.891\end{array}$ & $\begin{array}{l}0.76 \\
3.16 \\
2.92\end{array}$ \\
\hline $\begin{array}{l}\text { MARCH } \\
\text { Input C1 } \\
\text { Output WS1 } \\
\text { Output WS2 }\end{array}$ & $\begin{array}{l}0.320 \\
2.105 \\
1.621\end{array}$ & $\begin{array}{l}0.400 \\
1.814 \\
1.345\end{array}$ & $\begin{array}{l}0.220 \\
1.604 \\
1.568\end{array}$ & $\begin{array}{l}0.350 \\
0.703 \\
0.578\end{array}$ & $\begin{array}{l}2.470 \\
4.059 \\
3.834\end{array}$ & $\begin{array}{l}0.210 \\
2.478 \\
2.145\end{array}$ & $\begin{array}{l}0.060 \\
0.999 \\
0.865\end{array}$ & $\begin{array}{l}0.58 \\
1.97 \\
1.71\end{array}$ \\
\hline $\begin{array}{l}\text { APRIL } \\
\text { Input C1 } \\
\text { Output WS1 } \\
\text { Output WS2 }\end{array}$ & $\begin{array}{l}1.380 \\
2.022 \\
1.397\end{array}$ & $\begin{array}{l}0.290 \\
1.141 \\
0.837\end{array}$ & $\begin{array}{l}1.410 \\
1.410 \\
1.314\end{array}$ & $\begin{array}{l}0.773 \\
0.555\end{array}$ & $\begin{array}{l}0.490 \\
0.972 \\
0.919\end{array}$ & $\begin{array}{l}0.130 \\
1.063 \\
0.914\end{array}$ & $\begin{array}{l}0.110 \\
1.619 \\
1.431\end{array}$ & $\begin{array}{l}0.64 \\
1.29 \\
1.05\end{array}$ \\
\hline $\begin{array}{l}\text { MAY } \\
\text { Input C1 } \\
\text { Output WS1 } \\
\text { Output WS2 }\end{array}$ & $\begin{array}{l}0.990 \\
2.028 \\
1.451\end{array}$ & $\begin{array}{l}1.310 \\
1.005 \\
0.727\end{array}$ & $\begin{array}{l}0.640 \\
0.558 \\
0.469\end{array}$ & $\begin{array}{l}0.130 \\
0.416 \\
0.448\end{array}$ & $\begin{array}{l}1.270 \\
1.264 \\
1.244\end{array}$ & $\begin{array}{l}0.130 \\
1.972 \\
1.732\end{array}$ & $\begin{array}{l}0.200 \\
2.006 \\
1.802\end{array}$ & $\begin{array}{l}0.69 \\
1.32 \\
1.12\end{array}$ \\
\hline $\begin{array}{l}\text { JUNE } \\
\text { Input C1 } \\
\text { Output WS1 } \\
\text { Output WS2 }\end{array}$ & $\begin{array}{l}0.270 \\
0.026 \\
0.020\end{array}$ & $\begin{array}{l}0.860 \\
0.812 \\
0.625\end{array}$ & $\begin{array}{l}1.090 \\
0.223 \\
0.157\end{array}$ & $\begin{array}{l}0.070 \\
0.388 \\
0.303\end{array}$ & $\begin{array}{l}0.870 \\
0.000 \\
0.000\end{array}$ & $\begin{array}{l}0.150 \\
1.206 \\
0.987\end{array}$ & $\begin{array}{l}0.170 \\
0.470 \\
0.389\end{array}$ & $\begin{array}{l}0.50 \\
0.45 \\
0.35\end{array}$ \\
\hline $\begin{array}{l}\text { JULY } \\
\text { Input C1 } \\
\text { Output WS1 } \\
\text { Output WS2 }\end{array}$ & $\begin{array}{l}0.230 \\
0.725 \\
0.521\end{array}$ & $\begin{array}{l}0.750 \\
0.674 \\
0.535\end{array}$ & $\begin{array}{l}0.910 \\
1.024 \\
0.909\end{array}$ & $\begin{array}{l}0.550 \\
0.012 \\
0.011\end{array}$ & $\begin{array}{l}1.800 \\
0.349 \\
0.354\end{array}$ & $\begin{array}{l}0.200 \\
0.700 \\
0.581\end{array}$ & $\begin{array}{l}0.160 \\
0.459 \\
0.388\end{array}$ & $\begin{array}{l}0.66 \\
0.56 \\
0.47\end{array}$ \\
\hline $\begin{array}{l}\text { AUGUST } \\
\text { Input C1 } \\
\text { Output WS1 } \\
\text { Output WS2 }\end{array}$ & $\begin{array}{l}0.170 \\
0.393 \\
0.265\end{array}$ & $\begin{array}{l}0.230 \\
0.036 \\
0.029\end{array}$ & $\begin{array}{l}0.720 \\
0.067 \\
0.058\end{array}$ & $\begin{array}{l}1.460 \\
0.289 \\
0.294\end{array}$ & $\begin{array}{l}1.980 \\
0.342 \\
0.394\end{array}$ & $\begin{array}{l}0.200 \\
0.098 \\
0.079\end{array}$ & $\begin{array}{l}0.220 \\
0.139 \\
0.103\end{array}$ & $\begin{array}{l}0.71 \\
0.19 \\
0.17\end{array}$ \\
\hline $\begin{array}{l}\text { SEPTEMBER } \\
\text { Input C1 } \\
\text { Output WS1 } \\
\text { Output WS2 }\end{array}$ & $\begin{array}{l}0.330 \\
0.063 \\
0.044\end{array}$ & $\begin{array}{l}0.190 \\
0.008 \\
0.006\end{array}$ & $\begin{array}{l}0.510 \\
0.082 \\
0.064\end{array}$ & $\begin{array}{l}4.370 \\
0.397 \\
0.369\end{array}$ & $\begin{array}{l}2.150 \\
0.476 \\
0.479\end{array}$ & $\begin{array}{l}0.200 \\
0.225 \\
0.181\end{array}$ & $\begin{array}{l}0.280 \\
1.652 \\
1.508\end{array}$ & $\begin{array}{l}1.15 \\
0.41 \\
0.38\end{array}$ \\
\hline $\begin{array}{l}\text { OCTOBER } \\
\text { Input C1 } \\
\text { Output WS1 } \\
\text { Output WS2 }\end{array}$ & $\begin{array}{l}0.740 \\
1.252 \\
0.850\end{array}$ & $\begin{array}{l}0.350 \\
0.099 \\
0.079\end{array}$ & $\begin{array}{l}1.420 \\
1.027 \\
1.035\end{array}$ & $\begin{array}{l}2.470 \\
2.640 \\
2.490\end{array}$ & $\begin{array}{l}1.250 \\
1.186 \\
1.160\end{array}$ & $\begin{array}{l}0.460 \\
1.089 \\
0.959\end{array}$ & $\begin{array}{l}0.240 \\
2.283 \\
1.939\end{array}$ & $\begin{array}{l}0.94 \\
1.37 \\
1.22\end{array}$ \\
\hline $\begin{array}{l}\text { NOVEMBER } \\
\text { Input C1 } \\
\text { Output WS1 } \\
\text { Output WS2 }\end{array}$ & $\begin{array}{l}0.370 \\
1.248 \\
0.962\end{array}$ & $\begin{array}{l}4.870 \\
2.129 \\
1.597\end{array}$ & $\begin{array}{l}0.110 \\
1.589 \\
1.350\end{array}$ & $\begin{array}{l}3.730 \\
4.177 \\
3.968\end{array}$ & $\begin{array}{l}0.590 \\
2.120 \\
1.761\end{array}$ & $\begin{array}{l}0.210 \\
1.013 \\
0.804\end{array}$ & $\begin{array}{l}0.240 \\
1.587 \\
1.468\end{array}$ & $\begin{array}{l}1.45 \\
1.98 \\
1.70\end{array}$ \\
\hline $\begin{array}{l}\text { DECEMBER } \\
\text { Input C1 } \\
\text { Output WS1 } \\
\text { Output WS2 }\end{array}$ & $\begin{array}{l}0.170 \\
2.022 \\
1.535\end{array}$ & $\begin{array}{l}0.320 \\
2.008 \\
1.802\end{array}$ & $\begin{array}{l}0.190 \\
0.935 \\
0.813\end{array}$ & $\begin{array}{l}3.780 \\
3.112 \\
2.875\end{array}$ & $\begin{array}{l}0.480 \\
2.682 \\
2.452\end{array}$ & $\begin{array}{l}0.130 \\
0.963 \\
0.830\end{array}$ & $\begin{array}{l}0.420 \\
6.497 \\
5.454\end{array}$ & $\begin{array}{l}0.78 \\
2.60 \\
2.60\end{array}$ \\
\hline $\begin{array}{l}\text { ANNUAL SU } \\
\text { Input C1 } \\
\text { Output WS1 } \\
\text { Output WS2 } \\
\end{array}$ & $\begin{array}{r}1 S \\
5.520 \\
17.456 \\
13.185 \\
\end{array}$ & $\dot{.}$ & $\begin{array}{r}9.120 \\
15.428 \\
14.234 \\
\end{array}$ & $\begin{array}{l}14.983 \\
13.536 \\
\end{array}$ & $\begin{array}{l}19.510 \\
23.517 \\
22.220\end{array}$ & $\begin{array}{r}2.560 \\
19.775 \\
16.202 \\
\end{array}$ & $\begin{array}{r}2.270 \\
21.946 \\
18.973 \\
\end{array}$ & $\begin{array}{r}9.67 \\
18.29 \\
16.25 \\
\end{array}$ \\
\hline
\end{tabular}


Table 3. Monthly Means and Annual Sums (kg/ha) for Potassium.

\begin{tabular}{|c|c|c|c|c|c|c|c|c|}
\hline & 1984 & 1985 & 1986 & 1987 & 1988 & 1989 & 1990 & $\begin{array}{l}\text { Monthly } \\
\text { Average }\end{array}$ \\
\hline $\begin{array}{l}\text { JANUARY } \\
\text { Input C1 } \\
\text { Output WS1 } \\
\text { Output WS2 }\end{array}$ & $\begin{array}{l}0.020 \\
0.837 \\
1.003\end{array}$ & $\dot{.}$ & $\begin{array}{l}0.050 \\
0.178 \\
0.338\end{array}$ & $\begin{array}{l}0.180 \\
0.648 \\
0.452\end{array}$ & $\begin{array}{l}0.300 \\
0.431 \\
0.427\end{array}$ & $\begin{array}{l}0.040 \\
0.667 \\
0.570\end{array}$ & $\begin{array}{l}0.310 \\
0.618 \\
0.640\end{array}$ & $\begin{array}{l}0.15 \\
0.56 \\
0.57\end{array}$ \\
\hline $\begin{array}{l}\text { FEBRUARY } \\
\text { Input C1 } \\
\text { Output WS1 } \\
\text { Output WS2 }\end{array}$ & $\begin{array}{l}0.030 \\
1.449 \\
0.936\end{array}$ & $\begin{array}{c}1.211 \\
.\end{array}$ & $\begin{array}{l}0.330 \\
0.407 \\
0.449\end{array}$ & $\begin{array}{l}0.020 \\
0.315 \\
0.266\end{array}$ & $\begin{array}{l}0.920 \\
0.454 \\
0.411\end{array}$ & $\begin{array}{l}0.080 \\
0.848 \\
0.768\end{array}$ & $\begin{array}{l}0.080 \\
0.808 \\
0.714\end{array}$ & $\begin{array}{l}0.24 \\
0.78 \\
0.59\end{array}$ \\
\hline $\begin{array}{l}\text { MARCH } \\
\text { Input C1 } \\
\text { Output WS1 } \\
\text { Output WS2 }\end{array}$ & $\begin{array}{l}0.030 \\
1.359 \\
0.666\end{array}$ & $\begin{array}{l}0.020 \\
1.032 \\
0.568\end{array}$ & $\begin{array}{l}0.100 \\
0.408 \\
0.375\end{array}$ & $\begin{array}{l}0.070 \\
0.291 \\
0.272\end{array}$ & $\begin{array}{l}0.520 \\
0.393 \\
0.372\end{array}$ & $\begin{array}{l}0.630 \\
1.190 \\
1.018\end{array}$ & $\begin{array}{l}0.020 \\
0.341 \\
0.318\end{array}$ & $\begin{array}{l}0.20 \\
0.72 \\
0.51\end{array}$ \\
\hline $\begin{array}{l}\text { APRIL } \\
\text { Input C1 } \\
\text { Output WS1 } \\
\text { Output WS2 }\end{array}$ & $\begin{array}{l}0.120 \\
0.731 \\
0.713\end{array}$ & $\begin{array}{l}0.460 \\
0.492 \\
0.427\end{array}$ & $\begin{array}{l}0.460 \\
0.690 \\
0.476\end{array}$ & $\begin{array}{l}0.190 \\
0.477 \\
0.462\end{array}$ & $\begin{array}{l}0.550 \\
0.309 \\
0.264\end{array}$ & $\begin{array}{l}0.140 \\
0.481 \\
0.447\end{array}$ & $\begin{array}{l}0.040 \\
0.606 \\
0.612\end{array}$ & $\begin{array}{l}0.28 \\
0.54 \\
0.48\end{array}$ \\
\hline $\begin{array}{l}\text { MAY } \\
\text { Input C1 } \\
\text { Output WS1 } \\
\text { Output WS2 }\end{array}$ & $\begin{array}{l}0.550 \\
0.783 \\
0.758\end{array}$ & $\begin{array}{l}0.530 \\
0.398 \\
0.329\end{array}$ & $\begin{array}{l}0.320 \\
0.201 \\
0.156\end{array}$ & $\begin{array}{l}0.350 \\
0.419 \\
0.326\end{array}$ & $\begin{array}{l}0.460 \\
0.461 \\
0.399\end{array}$ & $\begin{array}{l}0.260 \\
0.909 \\
0.873\end{array}$ & $\begin{array}{l}0.220 \\
0.927 \\
0.820\end{array}$ & $\begin{array}{l}0.38 \\
0.58 \\
0.52\end{array}$ \\
\hline $\begin{array}{l}\text { JUNE } \\
\text { Input C1 } \\
\text { Output WS1 } \\
\text { Output WS2 }\end{array}$ & $\begin{array}{l}0.100 \\
0.014 \\
0.011\end{array}$ & $\begin{array}{l}0.190 \\
0.332 \\
0.297\end{array}$ & $\begin{array}{l}0.700 \\
0.043 \\
0.036\end{array}$ & $\begin{array}{l}0.180 \\
0.224 \\
0.127\end{array}$ & $\begin{array}{l}0.450 \\
0.000 \\
0.000\end{array}$ & $\begin{array}{l}0.420 \\
1.109 \\
0.442\end{array}$ & $\begin{array}{l}0.240 \\
0.218 \\
0.140\end{array}$ & $\begin{array}{l}0.32 \\
0.28 \\
0.15\end{array}$ \\
\hline $\begin{array}{l}\text { JULY } \\
\text { Input C1 } \\
\text { Output WS1 } \\
\text { Output WS2 }\end{array}$ & $\begin{array}{l}0.070 \\
0.315 \\
0.223\end{array}$ & $\begin{array}{l}0.230 \\
0.275 \\
0.229\end{array}$ & $\begin{array}{l}0.290 \\
0.297 \\
0.247\end{array}$ & $\begin{array}{l}0.220 \\
0.004 \\
0.002\end{array}$ & $\begin{array}{l}0.310 \\
0.184 \\
0.126\end{array}$ & $\begin{array}{l}0.390 \\
0.345 \\
0.283\end{array}$ & $\begin{array}{l}0.300 \\
0.229 \\
0.168\end{array}$ & $\begin{array}{l}0.26 \\
0.24 \\
0.18\end{array}$ \\
\hline $\begin{array}{l}\text { AUGUST } \\
\text { Input C1 } \\
\text { Output WS1 } \\
\text { Output WS2 } \\
\text { SEPTEMBER }\end{array}$ & $\begin{array}{l}0.290 \\
0.154 \\
0.108\end{array}$ & $\begin{array}{l}0.340 \\
0.011 \\
0.007\end{array}$ & $\begin{array}{l}0.800 \\
0.017 \\
0.019\end{array}$ & $\begin{array}{l}0.160 \\
0.113 \\
0.096\end{array}$ & $\begin{array}{l}0.330 \\
0.187 \\
0.150\end{array}$ & $\begin{array}{l}0.450 \\
0.046 \\
0.028\end{array}$ & $\begin{array}{l}0.310 \\
0.052 \\
0.040\end{array}$ & $\begin{array}{l}0.38 \\
0.08 \\
0.06\end{array}$ \\
\hline $\begin{array}{l}\text { SEPTEMBER } \\
\text { Input C1 } \\
\text { Output WS1 } \\
\text { Output WS2 }\end{array}$ & $\begin{array}{l}0.230 \\
0.026 \\
0.022\end{array}$ & $\begin{array}{l}0.080 \\
0.002 \\
0.001\end{array}$ & $\begin{array}{l}0.270 \\
0.033 \\
0.029\end{array}$ & $\begin{array}{l}0.210 \\
0.121 \\
0.074\end{array}$ & $\begin{array}{l}0.010 \\
0.122 \\
0.063\end{array}$ & $\begin{array}{l}0.580 \\
0.104 \\
0.070\end{array}$ & $\begin{array}{l}0.140 \\
0.435 \\
0.347\end{array}$ & $\begin{array}{l}0.22 \\
0.12 \\
0.09\end{array}$ \\
\hline $\begin{array}{l}\text { OCTOBER } \\
\text { Input C1 } \\
\text { Output WS1 } \\
\text { Output WS2 }\end{array}$ & $\begin{array}{l}0.540 \\
0.500 \\
0.457\end{array}$ & $\begin{array}{l}0.070 \\
0.017 \\
0.019\end{array}$ & $\begin{array}{l}0.450 \\
0.251 \\
0.203\end{array}$ & $\begin{array}{l}1.120 \\
0.821 \\
0.258\end{array}$ & $\begin{array}{l}0.600 \\
0.230 \\
0.196\end{array}$ & $\begin{array}{l}0.930 \\
0.323 \\
0.532\end{array}$ & $\begin{array}{l}1.420 \\
0.698 \\
0.610\end{array}$ & $\begin{array}{l}0.73 \\
0.41 \\
0.32\end{array}$ \\
\hline $\begin{array}{l}\text { NOVEMBER } \\
\text { Input C1 } \\
\text { Output WS1 } \\
\text { Output WS2 }\end{array}$ & $\begin{array}{l}0.180 \\
0.529 \\
0.409\end{array}$ & $\begin{array}{l}0.730 \\
0.319 \\
0.328\end{array}$ & $\begin{array}{l}6.610 \\
7.952 \\
7.419\end{array}$ & $\begin{array}{l}7.500 \\
1.261 \\
0.531\end{array}$ & $\begin{array}{l}0.170 \\
0.363 \\
0.333\end{array}$ & $\begin{array}{l}1.890 \\
0.340 \\
0.306\end{array}$ & $\begin{array}{l}0.790 \\
0.307 \\
0.283\end{array}$ & $\begin{array}{l}2.55 \\
1.58 \\
1.37\end{array}$ \\
\hline $\begin{array}{l}\text { DECEMBER } \\
\text { Input C1 } \\
\text { Output WS1 } \\
\text { Output WS2 }\end{array}$ & $\begin{array}{l}0.060 \\
0.861 \\
0.742\end{array}$ & $\begin{array}{l}0.020 \\
0.478 \\
0.402\end{array}$ & $\begin{array}{l}0.080 \\
0.640 \\
0.527\end{array}$ & $\begin{array}{l}1.220 \\
0.288 \\
0.239\end{array}$ & $\begin{array}{l}0.330 \\
0.509 \\
0.425\end{array}$ & $\begin{array}{l}0.600 \\
0.295 \\
0.276\end{array}$ & $\begin{array}{l}0.220 \\
1.409 \\
1.369\end{array}$ & $\begin{array}{l}0.36 \\
0.64 \\
0.57\end{array}$ \\
\hline $\begin{array}{l}\text { ANNUAL SUN } \\
\text { Input C1 } \\
\text { Output WS1 } \\
\text { Output WS2 } \\
\end{array}$ & $\begin{array}{l}\text { S } \\
2.220 \\
7.557 \\
6.049 \\
\end{array}$ & $\dot{.}$ & $\begin{array}{l}10.460 \\
11.117 \\
10.274 \\
\end{array}$ & $\begin{array}{r}11.430 \\
4.982 \\
3.106 \\
\end{array}$ & $\begin{array}{l}4.950 \\
3.644 \\
3.167 \\
\end{array}$ & $\begin{array}{l}6.400 \\
6.657 \\
5.615 \\
\end{array}$ & $\begin{array}{l}4.100 \\
6.647 \\
6.061 \\
\end{array}$ & $\begin{array}{l}6.07 \\
6.53 \\
4.93 \\
\end{array}$ \\
\hline
\end{tabular}


Table 4. Monthly Means and Annual Sums (kg/ha) for Magnesium.

\begin{tabular}{|c|c|c|c|c|c|c|c|c|}
\hline & 1984 & 1985 & 1986 & 1987 & 1988 & 1989 & 1990 & $\begin{array}{l}\text { Monthly } \\
\text { Average }\end{array}$ \\
\hline $\begin{array}{l}\text { JANUARY } \\
\text { Input C1 } \\
\text { Output WS1 } \\
\text { Output WS2 }\end{array}$ & $\begin{array}{l}0.020 \\
1.715 \\
1.192\end{array}$ & $\dot{.}$ & $\begin{array}{l}0.110 \\
1.716 \\
1.624\end{array}$ & $\begin{array}{l}0.050 \\
2.299 \\
1.349\end{array}$ & $\begin{array}{l}0.180 \\
2.113 \\
1.295\end{array}$ & $\begin{array}{l}0.000 \\
1.360 \\
0.767\end{array}$ & $\begin{array}{l}0.030 \\
1.109 \\
0.727\end{array}$ & $\begin{array}{l}0.060 \\
1.720 \\
1.160\end{array}$ \\
\hline $\begin{array}{l}\text { FEBRUARY } \\
\text { Input C1 } \\
\text { Output WS1 } \\
\text { Output WS2 }\end{array}$ & $\begin{array}{l}0.040 \\
2.051 \\
1.434\end{array}$ & 1.645 & $\begin{array}{l}0.070 \\
1.979 \\
1.411\end{array}$ & $\begin{array}{l}0.000 \\
2.365 \\
1.388\end{array}$ & & $\begin{array}{l}0.050 \\
1.866 \\
1.107\end{array}$ & $\begin{array}{l}0.010 \\
1.142 \\
0.761\end{array}$ & $\begin{array}{l}0.330 \\
1.854 \\
1.211\end{array}$ \\
\hline $\begin{array}{l}\text { MARCH } \\
\text { Input C1 } \\
\text { Output WS1 } \\
\text { Output WS2 }\end{array}$ & $\begin{array}{l}0.030 \\
1.490 \\
1.049\end{array}$ & $\begin{array}{l}0.040 \\
1.247 \\
0.924\end{array}$ & $\begin{array}{l}0.030 \\
1.020 \\
0.790\end{array}$ & $\begin{array}{l}0.090 \\
1.473 \\
0.896\end{array}$ & & $\begin{array}{l}0.010 \\
1.438 \\
0.898\end{array}$ & & $\begin{array}{l}0.040 \\
1.267 \\
0.846\end{array}$ \\
\hline $\begin{array}{l}\text { APRIL } \\
\text { Input C1 } \\
\text { Output WS1 } \\
\text { Output WS2 }\end{array}$ & $\begin{array}{l}0.100 \\
1.638 \\
1.055\end{array}$ & $\begin{array}{l}0.030 \\
0.939 \\
0.572\end{array}$ & $\begin{array}{l}0.240 \\
0.879 \\
0.611\end{array}$ & & & & & $\begin{array}{l}0.060 \\
1.229 \\
0.771\end{array}$ \\
\hline $\begin{array}{l}\text { MAY } \\
\text { Input C1 } \\
\text { Output WS1 } \\
\text { Output WS2 }\end{array}$ & $\begin{array}{l}0.130 \\
1.695 \\
1.110\end{array}$ & $\begin{array}{l}0.170 \\
0.823 \\
0.531\end{array}$ & $\begin{array}{l}0.130 \\
0.309 \\
0.214\end{array}$ & $\begin{array}{l}0.130 \\
1.728 \\
1.104\end{array}$ & & & & $\begin{array}{l}0.100 \\
1.286 \\
0.892\end{array}$ \\
\hline $\begin{array}{l}\text { JUNE } \\
\text { Input C1 } \\
\text { Output WS1 } \\
\text { Output WS2 }\end{array}$ & $\begin{array}{l}0.040 \\
0.025 \\
0.016\end{array}$ & $\begin{array}{l}0.130 \\
0.649 \\
0.468\end{array}$ & $\begin{array}{l}0.240 \\
0.115 \\
0.078\end{array}$ & & & & & $\begin{array}{l}0.130 \\
0.458 \\
0.295\end{array}$ \\
\hline $\begin{array}{l}\text { JULY } \\
\text { Input C1 } \\
\text { Output WS1 } \\
\text { Output WS2 }\end{array}$ & $\begin{array}{l}0.030 \\
0.647 \\
0.416\end{array}$ & $\begin{array}{l}0.150 \\
0.568 \\
0.402\end{array}$ & $\begin{array}{l}0.170 \\
0.743 \\
0.488\end{array}$ & $\begin{array}{l}0.050 \\
0.014 \\
0.008\end{array}$ & & & & $\begin{array}{l}0.080 \\
0.470 \\
0.295\end{array}$ \\
\hline $\begin{array}{l}\text { AUGUST } \\
\text { Input C1 } \\
\text { Output WS1 } \\
\text { Output WS2 } \\
\text { SEPTEMBER }\end{array}$ & $\begin{array}{l}0.060 \\
0.342 \\
0.219\end{array}$ & $\begin{array}{l}0.070 \\
0.025 \\
0.019\end{array}$ & $\begin{array}{l}0.130 \\
0.036 \\
0.025\end{array}$ & & & & & $\begin{array}{l}0.050 \\
0.167 \\
0.104\end{array}$ \\
\hline $\begin{array}{l}\text { SEPTEMBER } \\
\text { Input C1 } \\
\text { Output WS1 } \\
\text { Output WS2 }\end{array}$ & $\begin{array}{l}0.050 \\
0.052 \\
0.034\end{array}$ & $\begin{array}{l}0.090 \\
0.008 \\
0.005\end{array}$ & $\begin{array}{l}0.090 \\
0.037 \\
0.024\end{array}$ & $\begin{array}{l}0.070 \\
0.176 \\
0.105\end{array}$ & & & & \\
\hline $\begin{array}{l}\text { OCTOBER } \\
\text { Input C1 } \\
\text { Output WS1 } \\
\text { Output WS2 }\end{array}$ & $\begin{array}{l}0.130 \\
1.005 \\
0.660\end{array}$ & $\begin{array}{l}0.110 \\
0.059 \\
0.041\end{array}$ & $\begin{array}{l}0.220 \\
0.444 \\
0.408\end{array}$ & $\begin{array}{l}0.050 \\
1.145 \\
0.769\end{array}$ & $\begin{array}{l}0.020 \\
0.739 \\
0.469\end{array}$ & & & $\begin{array}{l}0.090 \\
0.781 \\
0.532\end{array}$ \\
\hline $\begin{array}{l}\text { NOVEMBER } \\
\text { Input C1 } \\
\text { Output WS1 } \\
\text { Output WS2 }\end{array}$ & $\begin{array}{l}0.070 \\
1.134 \\
0.745\end{array}$ & $\begin{array}{l}3.060 \\
1.065 \\
0.754\end{array}$ & $\begin{array}{l}0.590 \\
3.734 \\
2.621\end{array}$ & $\begin{array}{l}0.100 \\
1.760 \\
1.265\end{array}$ & $\begin{array}{l}0.010 \\
0.787 \\
0.463\end{array}$ & $\begin{array}{l}0.050 \\
0.648 \\
0.372\end{array}$ & & $\begin{array}{l}0.650 \\
1.434 \\
0.979\end{array}$ \\
\hline $\begin{array}{l}\text { DECEMBER } \\
\text { Input C1 } \\
\text { Output WS1 } \\
\text { Output WS2 }\end{array}$ & $\begin{array}{l}0.020 \\
2.097 \\
1.268\end{array}$ & $\begin{array}{l}0.010 \\
1.639 \\
1.205\end{array}$ & $\begin{array}{l}0.090 \\
2.881 \\
1.798\end{array}$ & $\begin{array}{l}0.030 \\
1.301 \\
0.826\end{array}$ & & & & $\begin{array}{l}0.051 \\
1.943 \\
1.280\end{array}$ \\
\hline $\begin{array}{l}\text { ANNUAL SU } \\
\text { Input C1 } \\
\text { Output WS1 } \\
\text { Output WS2 } \\
\end{array}$ & $\begin{array}{r}\text { IS } \\
0.720 \\
13.890 \\
9.196 \\
\end{array}$ & $\dot{.}$ & $\begin{array}{r}2.110 \\
13.893 \\
10.093 \\
\end{array}$ & $\begin{array}{r}0.610 \\
15.851 \\
9.806 \\
\end{array}$ & $\begin{array}{r}0.750 \\
12.119 \\
7.417 \\
\end{array}$ & $\begin{array}{r}0.430 \\
10.005 \\
6.275 \\
\end{array}$ & $\begin{array}{r}0.580 \\
13.982 \\
9.658 \\
\end{array}$ & $\begin{array}{r}1.400 \\
12.880 \\
8.690 \\
\end{array}$ \\
\hline
\end{tabular}


Table 5. Monthly Means and Annual Sums (kg/ha) for Sodium.

\begin{tabular}{|c|c|c|c|c|c|c|c|c|}
\hline & 1984 & 1985 & 1986 & 1987 & 1988 & 1989 & 1990 & $\begin{array}{l}\text { Monthly } \\
\text { Average }\end{array}$ \\
\hline $\begin{array}{l}\text { JANUARY } \\
\text { Input C1 } \\
\text { Output WS1 } \\
\text { Output WS2 }\end{array}$ & $\begin{array}{l}0.0010 \\
0.2492 \\
0.1983\end{array}$ & $\dot{.}$ & $\begin{array}{l}0.3660 \\
0.3248 \\
0.1585\end{array}$ & & $\begin{array}{l}1.0580 \\
0.5979 \\
0.4784\end{array}$ & $\begin{array}{l}0.0490 \\
0.5963 \\
0.3422\end{array}$ & $\begin{array}{l}0.1690 \\
0.7532 \\
0.4333\end{array}$ & $\begin{array}{l}0.505 \\
0.546 \\
0.324\end{array}$ \\
\hline $\begin{array}{l}\text { FEBRUARY } \\
\text { Input C1 } \\
\text { Output WS1 } \\
\text { Output WS2 }\end{array}$ & $\begin{array}{l}0.0010 \\
0.2985 \\
0.2903\end{array}$ & 0.2987 & $\begin{array}{l}0.1880 \\
0.2662 \\
0.2130\end{array}$ & & & & & $\begin{array}{l}0.350 \\
0.559 \\
0.434\end{array}$ \\
\hline $\begin{array}{l}\text { MARCH } \\
\text { Input C1 } \\
\text { Output WS1 } \\
\text { Output WS2 }\end{array}$ & & $\begin{array}{l}0.0010 \\
0.2571 \\
0.2353\end{array}$ & & & & & & $\begin{array}{l}0.373 \\
0.517 \\
0.347\end{array}$ \\
\hline $\begin{array}{l}\text { APRIL } \\
\text { Input C1 } \\
\text { Output WS1 } \\
\text { Output WS2 }\end{array}$ & & $\begin{array}{l}0.0230 \\
0.1908 \\
0.1497\end{array}$ & & & & & & $\begin{array}{l}0.274 \\
0.468 \\
0.308\end{array}$ \\
\hline $\begin{array}{l}\text { MAY } \\
\text { Input C1 } \\
\text { Output WS1 } \\
\text { Output WS2 }\end{array}$ & & $\begin{array}{l}0.1000 \\
0.1804 \\
0.1375\end{array}$ & & & & & & $\begin{array}{l}0.259 \\
0.637 \\
0.411\end{array}$ \\
\hline $\begin{array}{l}\text { JUNE } \\
\text { Input C1 } \\
\text { Output WS1 } \\
\text { Output WS2 }\end{array}$ & & $\begin{array}{l}0.0630 \\
0.1626 \\
0.1238\end{array}$ & & & & & & $\begin{array}{l}0.429 \\
0.182 \\
0.124\end{array}$ \\
\hline $\begin{array}{l}\text { JULY } \\
\text { Input C1 } \\
\text { Output WS1 } \\
\text { Output WS2 }\end{array}$ & & $\begin{array}{l}0.0560 \\
0.1448 \\
0.1065\end{array}$ & $\begin{array}{l}0.7830 \\
0.2180 \\
0.1749\end{array}$ & & & & & $\begin{array}{l}0.205 \\
0.172 \\
0.118\end{array}$ \\
\hline $\begin{array}{l}\text { AUGUST } \\
\text { Input C1 } \\
\text { Output WS1 } \\
\text { Output WS2 }\end{array}$ & & & & & & & & $\begin{array}{l}0.477 \\
0.074 \\
0.056\end{array}$ \\
\hline $\begin{array}{l}\text { C1 } \\
\text { WS1 } \\
\text { WS2 }\end{array}$ & & & & & & & & $\begin{array}{l}0.152 \\
0.117 \\
0.073\end{array}$ \\
\hline $\begin{array}{l}\text { OCTOBER } \\
\text { Input C1 } \\
\text { Output WS1 } \\
\text { Output WS2 }\end{array}$ & $\begin{array}{l}0.0470 \\
0.2300 \\
0.1751\end{array}$ & $\begin{array}{l}0.6040 \\
0.0355 \\
0.0279\end{array}$ & & & & & & $\begin{array}{l}0.335 \\
0.352 \\
0.205\end{array}$ \\
\hline $\begin{array}{l}\text { NOVEMBER } \\
\text { Input C1 } \\
\text { Output WS1 } \\
\text { Output WS2 }\end{array}$ & $\begin{array}{l}0.0290 \\
0.2468 \\
0.1867\end{array}$ & $\begin{array}{l}1.0440 \\
0.2839 \\
0.2306\end{array}$ & $\begin{array}{l}0.2350 \\
0.9453 \\
0.6355\end{array}$ & $\begin{array}{l}1.7150 \\
0.4676 \\
0.3198\end{array}$ & & & & $\begin{array}{l}0.482 \\
0.426 \\
0.276\end{array}$ \\
\hline $\begin{array}{l}\text { DECEMBER } \\
\text { Input C1 } \\
\text { Output WS1 } \\
\text { Output WS2 }\end{array}$ & $\begin{array}{l}0.0160 \\
0.3715 \\
0.3096\end{array}$ & $\begin{array}{l}0.1650 \\
0.5319 \\
0.2931\end{array}$ & $\begin{array}{l}0.0260 \\
0.5570 \\
0.4181\end{array}$ & $\begin{array}{l}0.9640 \\
0.3271 \\
0.2954\end{array}$ & & & & $\begin{array}{l}0.532 \\
0.538 \\
0.374\end{array}$ \\
\hline $\begin{array}{l}\text { iput C1 } \\
\text { utput WS1 } \\
\text { utput WS2 }\end{array}$ & $\begin{array}{l}0.3800 \\
2.5657 \\
2.1523 \\
\end{array}$ & • & $\begin{array}{l}7.6700 \\
3.5441 \\
2.6552 \\
\end{array}$ & $\begin{array}{l}5.3250 \\
4.4391 \\
3.0123 \\
\end{array}$ & $\begin{array}{l}6.8070 \\
4.1039 \\
2.4609 \\
\end{array}$ & $\begin{array}{l}3.8700 \\
8.2642 \\
5.0581 \\
\end{array}$ & $\begin{array}{l}2.6830 \\
6.5461 \\
3.9328 \\
\end{array}$ & $\begin{array}{l}0.364 \\
0.382 \\
0.254\end{array}$ \\
\hline
\end{tabular}


Table 6. Monthly Means and Annual Sums (kg/ha) for Phosphate.

\begin{tabular}{|c|c|c|c|c|c|c|c|c|}
\hline & 1984 & 1985 & 1986 & 1987 & 1988 & 1989 & 1990 & $\begin{array}{l}\text { Monthly } \\
\text { Average }\end{array}$ \\
\hline $\begin{array}{l}\text { JANUARY } \\
\text { Input C1 } \\
\text { Output WS1 } \\
\text { Output WS2 }\end{array}$ & $\dot{.}$ & $\dot{.}$ & $\begin{array}{l}0.240 \\
0.301 \\
0.327\end{array}$ & $\begin{array}{l}0.150 \\
0.391 \\
0.000\end{array}$ & $\begin{array}{l}1.320 \\
1.515 \\
1.467\end{array}$ & $\begin{array}{l}1.480 \\
1.803 \\
1.803\end{array}$ & $\begin{array}{l}0.260 \\
0.426 \\
0.491\end{array}$ & $\begin{array}{l}0.690 \\
0.887 \\
0.818\end{array}$ \\
\hline $\begin{array}{l}\text { FEBRUARY } \\
\text { Input C1 } \\
\text { Output WS1 } \\
\text { Output WS2 }\end{array}$ & $\dot{.}$ & $\dot{.}$ & $\begin{array}{l}0.420 \\
0.091 \\
0.112\end{array}$ & $\begin{array}{l}0.000 \\
0.278 \\
0.000\end{array}$ & $\begin{array}{l}1.480 \\
1.273 \\
1.243\end{array}$ & $\begin{array}{l}1.920 \\
3.014 \\
2.523\end{array}$ & $\begin{array}{l}0.310 \\
1.336 \\
0.867\end{array}$ & $\begin{array}{l}0.826 \\
1.198 \\
0.949\end{array}$ \\
\hline $\begin{array}{l}\text { MARCH } \\
\text { Input C1 } \\
\text { Output WS1 } \\
\text { Output WS2 }\end{array}$ & $\dot{.}$ & $\dot{.}$ & $\begin{array}{l}0.360 \\
0.083 \\
0.130\end{array}$ & $\begin{array}{l}0.110 \\
0.223 \\
0.118\end{array}$ & $\begin{array}{l}1.140 \\
1.184 \\
1.119\end{array}$ & $\begin{array}{l}1.890 \\
2.713 \\
2.527\end{array}$ & $\begin{array}{l}0.250 \\
0.540 \\
0.496\end{array}$ & $\begin{array}{l}0.750 \\
0.949 \\
0.878\end{array}$ \\
\hline $\begin{array}{l}\text { APRIL } \\
\text { Input C1 } \\
\text { Output WS1 } \\
\text { Output WS2 }\end{array}$ & . & $\dot{.}$ & $\begin{array}{l}0.180 \\
0.056 \\
0.067\end{array}$ & $\begin{array}{l}0.410 \\
0.490 \\
0.229\end{array}$ & $\begin{array}{l}0.980 \\
1.080 \\
1.074\end{array}$ & $\begin{array}{l}0.670 \\
0.986 \\
0.863\end{array}$ & & $\begin{array}{l}0.592 \\
0.719 \\
0.617\end{array}$ \\
\hline $\begin{array}{l}\text { MAY } \\
\text { Input C1 } \\
\text { Output WS1 } \\
\text { Output WS2 }\end{array}$ & $\dot{.}$ & $\dot{.}$ & $\begin{array}{l}0.200 \\
0.048 \\
0.046\end{array}$ & $\begin{array}{l}1.960 \\
0.842 \\
1.049\end{array}$ & $\begin{array}{l}1.750 \\
1.347 \\
1.193\end{array}$ & $\begin{array}{l}0.860 \\
0.235 \\
0.000\end{array}$ & $\begin{array}{l}1.800 \\
1.691 \\
1.669\end{array}$ & $\begin{array}{l}1.314 \\
0.833 \\
0.791\end{array}$ \\
\hline $\begin{array}{l}\text { JUNE } \\
\text { Input C1 } \\
\text { Output WS1 } \\
\text { Output WS2 }\end{array}$ & $\dot{.}$ & $\dot{.}$ & $\begin{array}{l}0.540 \\
0.016 \\
0.011\end{array}$ & $\begin{array}{l}2.940 \\
1.056 \\
1.152\end{array}$ & $\begin{array}{l}0.910 \\
0.000 \\
0.000\end{array}$ & $\begin{array}{l}0.720 \\
0.273 \\
0.236\end{array}$ & $\begin{array}{l}1.360 \\
0.489 \\
0.425\end{array}$ & $\begin{array}{l}1.294 \\
0.367 \\
0.365\end{array}$ \\
\hline $\begin{array}{l}\text { JULY } \\
\text { Input C1 } \\
\text { Output WS1 } \\
\text { Output WS2 }\end{array}$ & $\dot{.}$ & $\dot{.}$ & $\begin{array}{l}0.370 \\
0.075 \\
0.069\end{array}$ & $\begin{array}{l}0.890 \\
0.014 \\
0.018\end{array}$ & $\begin{array}{l}1.650 \\
0.376 \\
0.259\end{array}$ & $\begin{array}{l}1.600 \\
0.884 \\
0.750\end{array}$ & $\begin{array}{l}0.730 \\
0.424 \\
0.398\end{array}$ & $\begin{array}{l}1.048 \\
0.355 \\
0.298\end{array}$ \\
\hline $\begin{array}{l}\text { AUGUST } \\
\text { Input C1 } \\
\text { Output WS1 } \\
\text { Output WS2 }\end{array}$ & $\dot{.}$ & $\begin{array}{l}0.070 \\
0.002 \\
0.004\end{array}$ & $\begin{array}{l}0.090 \\
0.003 \\
0.005\end{array}$ & $\begin{array}{l}1.830 \\
0.322 \\
0.323\end{array}$ & $\begin{array}{l}1.330 \\
0.286 \\
0.305\end{array}$ & $\begin{array}{l}0.870 \\
0.084 \\
0.094\end{array}$ & $\begin{array}{l}1.020 \\
0.124 \\
0.099\end{array}$ & $\begin{array}{l}0.868 \\
0.137 \\
0.138\end{array}$ \\
\hline $\begin{array}{l}\text { SEPTEMBER } \\
\text { Input C1 } \\
\text { Output WS1 } \\
\text { Output WS2 }\end{array}$ & $\dot{.}$ & $\begin{array}{l}0.190 \\
0.001 \\
0.002\end{array}$ & $\begin{array}{l}0.080 \\
0.002 \\
0.003\end{array}$ & $\begin{array}{l}1.440 \\
0.128 \\
0.113\end{array}$ & $\begin{array}{l}1.650 \\
0.424 \\
0.370\end{array}$ & $\begin{array}{l}0.620 \\
0.103 \\
0.095\end{array}$ & $\begin{array}{l}1.560 \\
0.865 \\
0.945\end{array}$ & $\begin{array}{l}0.923 \\
0.254 \\
0.255\end{array}$ \\
\hline $\begin{array}{l}\text { OCTOBER } \\
\text { Input C1 } \\
\text { Output WS1 } \\
\text { Output WS2 }\end{array}$ & $\dot{.}$ & $\begin{array}{l}0.140 \\
0.004 \\
0.016\end{array}$ & $\begin{array}{l}0.100 \\
0.051 \\
0.046\end{array}$ & $\begin{array}{l}0.860 \\
0.837 \\
0.784\end{array}$ & $\begin{array}{l}1.070 \\
0.684 \\
0.805\end{array}$ & $\begin{array}{l}1.060 \\
0.000 \\
0.015\end{array}$ & $\begin{array}{l}1.510 \\
0.987 \\
1.037\end{array}$ & $\begin{array}{l}0.790 \\
0.427 \\
0.451\end{array}$ \\
\hline $\begin{array}{l}\text { NOVEMBER } \\
\text { Input C1 } \\
\text { Output WS1 } \\
\text { Output WS2 }\end{array}$ & $\dot{.}$ & $\begin{array}{l}0.030 \\
0.080 \\
0.044\end{array}$ & $\begin{array}{l}0.000 \\
0.095 \\
0.000\end{array}$ & $\begin{array}{l}2.940 \\
1.236 \\
1.335\end{array}$ & $\begin{array}{l}0.840 \\
1.066 \\
0.828\end{array}$ & $\begin{array}{l}0.350 \\
0.034 \\
0.018\end{array}$ & $\begin{array}{l}0.460 \\
0.585 \\
0.592\end{array}$ & $\begin{array}{l}0.765 \\
0.516 \\
0.470\end{array}$ \\
\hline $\begin{array}{l}\text { DECEMBER } \\
\text { Input C1 } \\
\text { Output WS1 } \\
\text { Output WS2 }\end{array}$ & $\dot{.}$ & $\begin{array}{l}0.030 \\
0.054 \\
0.141\end{array}$ & $\begin{array}{l}2.030 \\
0.000 \\
0.000\end{array}$ & $\begin{array}{l}2.380 \\
1.122 \\
1.339\end{array}$ & $\begin{array}{l}0.890 \\
1.667 \\
1.433\end{array}$ & $\begin{array}{l}0.190 \\
0.240 \\
0.240\end{array}$ & $\begin{array}{l}2.490 \\
2.102 \\
2.348\end{array}$ & $\begin{array}{l}1.335 \\
0.864 \\
0.917\end{array}$ \\
\hline $\begin{array}{l}\text { ANNUAL SUMS } \\
\text { Input C1 } \\
\text { Output WS1 } \\
\text { Output WS2 }\end{array}$ & : & $\dot{ }$ & $\begin{array}{l}4.610 \\
0.823 \\
0.818 \\
\end{array}$ & $\begin{array}{r}15.920 \\
6.938 \\
6.450 \\
\end{array}$ & $\begin{array}{l}15.030 \\
10.902 \\
10.096\end{array}$ & $\begin{array}{r}12.220 \\
10.372 \\
9.165\end{array}$ & $\begin{array}{l}12.470 \\
10.552 \\
10.217 \\
\end{array}$ & $\begin{array}{r}11.196 \\
7.505 \\
6.946 \\
\end{array}$ \\
\hline
\end{tabular}


Table 7. Monthly Means and Annual Sums (kg/ha) for Nitrate.

\begin{tabular}{|c|c|c|c|c|c|c|c|c|}
\hline & 1984 & 1985 & 1986 & 1987 & 1988 & 1989 & 1990 & $\begin{array}{l}\text { Monthly } \\
\text { Average }\end{array}$ \\
\hline $\begin{array}{l}\text { JANUARY } \\
\text { Input C1 } \\
\text { Output WS1 } \\
\text { Output WS2 }\end{array}$ & $\begin{array}{l}0.540 \\
0.680 \\
0.443\end{array}$ & $\dot{.}$ & $\begin{array}{l}0.380 \\
1.074 \\
0.354\end{array}$ & $\begin{array}{l}0.810 \\
0.769 \\
0.319\end{array}$ & $\begin{array}{l}1.020 \\
1.785 \\
1.570\end{array}$ & $\begin{array}{l}1.250 \\
1.510 \\
1.360\end{array}$ & $\begin{array}{l}1.250 \\
1.643 \\
1.185\end{array}$ & $\begin{array}{l}0.88 \\
1.24 \\
0.87\end{array}$ \\
\hline $\begin{array}{l}\text { FEBRUARY } \\
\text { Input C1 } \\
\text { Output WS1 } \\
\text { Output WS2 }\end{array}$ & $\begin{array}{l}0.750 \\
0.880 \\
0.545\end{array}$ & 1.060 & $\begin{array}{l}8.180 \\
3.740 \\
3.631\end{array}$ & $\begin{array}{l}0.620 \\
1.070 \\
0.816\end{array}$ & $\begin{array}{l}1.520 \\
1.520 \\
1.437\end{array}$ & $\begin{array}{l}1.750 \\
2.101 \\
1.861\end{array}$ & $\begin{array}{l}0.590 \\
1.833 \\
1.227\end{array}$ & $\begin{array}{l}2.24 \\
1.74 \\
1.59\end{array}$ \\
\hline $\begin{array}{l}\text { MARCH } \\
\text { Input C1 } \\
\text { Output WS1 } \\
\text { Output WS2 }\end{array}$ & $\begin{array}{l}1.620 \\
0.646 \\
0.496\end{array}$ & $\begin{array}{l}0.890 \\
0.496 \\
0.382\end{array}$ & $\begin{array}{l}4.760 \\
1.663 \\
1.517\end{array}$ & $\begin{array}{l}1.140 \\
0.820 \\
0.685\end{array}$ & $\begin{array}{l}1.290 \\
1.368 \\
1.216\end{array}$ & $\begin{array}{l}1.610 \\
2.381 \\
2.100\end{array}$ & $\begin{array}{l}0.330 \\
0.751 \\
0.545\end{array}$ & $\begin{array}{l}1.66 \\
1.16 \\
0.99\end{array}$ \\
\hline $\begin{array}{l}\text { APRIL } \\
\text { Input C1 } \\
\text { Output WS1 } \\
\text { Output WS2 }\end{array}$ & $\begin{array}{l}1.410 \\
0.567 \\
0.627\end{array}$ & $\begin{array}{l}0.580 \\
0.419 \\
0.371\end{array}$ & $\begin{array}{l}4.960 \\
0.897 \\
0.786\end{array}$ & $\begin{array}{l}2.010 \\
1.367 \\
1.195\end{array}$ & $\begin{array}{l}0.900 \\
1.029 \\
0.996\end{array}$ & $\begin{array}{l}0.780 \\
0.575 \\
0.472\end{array}$ & $\begin{array}{l}0.680 \\
1.069 \\
0.779\end{array}$ & $\begin{array}{l}1.62 \\
0.85 \\
0.75\end{array}$ \\
\hline $\begin{array}{l}\text { MAY } \\
\text { Input C1 } \\
\text { Output WS1 } \\
\text { Output WS2 }\end{array}$ & $\begin{array}{l}0.820 \\
0.517 \\
0.339\end{array}$ & $\begin{array}{l}1.990 \\
0.340 \\
0.345\end{array}$ & $\begin{array}{l}0.690 \\
0.543 \\
0.269\end{array}$ & $\begin{array}{l}2.940 \\
1.421 \\
1.452\end{array}$ & $\begin{array}{l}1.580 \\
1.224 \\
1.131\end{array}$ & $\begin{array}{l}2.010 \\
0.805 \\
0.706\end{array}$ & $\begin{array}{l}1.510 \\
2.033 \\
1.246\end{array}$ & $\begin{array}{l}1.65 \\
0.98 \\
0.79\end{array}$ \\
\hline $\begin{array}{l}\text { JUNE } \\
\text { Input C1 } \\
\text { Output WS1 } \\
\text { Output WS2 }\end{array}$ & $\begin{array}{l}0.400 \\
0.006 \\
0.002\end{array}$ & $\begin{array}{l}0.590 \\
0.237 \\
0.212\end{array}$ & $\begin{array}{l}4.690 \\
0.125 \\
0.052\end{array}$ & $\begin{array}{l}2.620 \\
0.820 \\
0.641\end{array}$ & $\begin{array}{l}1.370 \\
0.000 \\
0.000\end{array}$ & $\begin{array}{l}1.470 \\
0.497 \\
0.428\end{array}$ & $\begin{array}{l}1.080 \\
0.370 \\
0.233\end{array}$ & $\begin{array}{l}1.75 \\
0.29 \\
0.22\end{array}$ \\
\hline $\begin{array}{l}\text { JULY } \\
\text { Input C1 } \\
\text { Output WS1 } \\
\text { Output WS2 }\end{array}$ & $\begin{array}{l}0.830 \\
0.147 \\
0.043\end{array}$ & $\begin{array}{l}1.050 \\
0.191 \\
0.130\end{array}$ & $\begin{array}{l}4.210 \\
1.060 \\
0.656\end{array}$ & $\begin{array}{l}1.210 \\
0.014 \\
0.012\end{array}$ & $\begin{array}{l}1.650 \\
0.268 \\
0.268\end{array}$ & $\begin{array}{l}2.420 \\
0.596 \\
0.633\end{array}$ & $\begin{array}{l}0.780 \\
0.433 \\
0.375\end{array}$ & $\begin{array}{l}1.74 \\
0.39 \\
0.30\end{array}$ \\
\hline $\begin{array}{l}\text { AUGUST } \\
\text { Input C1 } \\
\text { Output WS1 } \\
\text { Output WS2 }\end{array}$ & $\begin{array}{l}0.880 \\
0.090 \\
0.042\end{array}$ & $\begin{array}{l}0.160 \\
0.101 \\
0.055\end{array}$ & $\begin{array}{l}1.850 \\
0.038 \\
0.019\end{array}$ & $\begin{array}{l}1.640 \\
0.278 \\
0.257\end{array}$ & $\begin{array}{l}1.590 \\
0.316 \\
0.305\end{array}$ & $\begin{array}{l}0.540 \\
0.056 \\
0.037\end{array}$ & $\begin{array}{l}0.890 \\
0.096 \\
0.074\end{array}$ & $\begin{array}{l}1.07 \\
0.14 \\
0.11\end{array}$ \\
\hline $\begin{array}{l}\text { SEPTEMBER } \\
\text { Input C1 } \\
\text { Output WS1 } \\
\text { Output WS2 }\end{array}$ & $\dot{.}$ & $\begin{array}{l}0.990 \\
0.005 \\
0.003\end{array}$ & $\begin{array}{l}1.090 \\
0.032 \\
0.014\end{array}$ & $\begin{array}{l}2.060 \\
0.164 \\
0.144\end{array}$ & $\begin{array}{l}1.650 \\
0.336 \\
0.302\end{array}$ & $\begin{array}{l}0.920 \\
0.140 \\
0.106\end{array}$ & $\begin{array}{l}1.450 \\
0.845 \\
0.756\end{array}$ & $\begin{array}{l}1.36 \\
0.26 \\
0.22\end{array}$ \\
\hline $\begin{array}{l}\text { OCTOBER } \\
\text { Input C1 } \\
\text { Output WS1 } \\
\text { Output WS2 }\end{array}$ & $\dot{.}$ & $\begin{array}{l}2.250 \\
0.032 \\
0.019\end{array}$ & $\begin{array}{l}3.900 \\
1.586 \\
1.053\end{array}$ & $\begin{array}{l}1.530 \\
0.958 \\
0.845\end{array}$ & $\begin{array}{l}1.660 \\
0.726 \\
0.595\end{array}$ & $\begin{array}{l}1.180 \\
0.829 \\
0.494\end{array}$ & $\begin{array}{l}0.890 \\
1.206 \\
0.932\end{array}$ & $\begin{array}{l}1.90 \\
0.89 \\
0.66\end{array}$ \\
\hline $\begin{array}{l}\text { NOVEMBER } \\
\text { Input C1 } \\
\text { Output WS1 } \\
\text { Output WS2 }\end{array}$ & $\dot{.}$ & $\begin{array}{l}1.597 \\
0.408\end{array}$ & $\begin{array}{l}1.120 \\
1.112 \\
1.096\end{array}$ & $\begin{array}{l}2.840 \\
1.556 \\
1.357\end{array}$ & $\begin{array}{l}0.950 \\
0.992 \\
0.815\end{array}$ & $\begin{array}{l}1.490 \\
0.774 \\
0.426\end{array}$ & $\begin{array}{l}0.510 \\
0.695 \\
0.592\end{array}$ & $\begin{array}{l}1.19 \\
1.12 \\
0.78\end{array}$ \\
\hline $\begin{array}{l}\text { DECEMBER } \\
\text { Input C1 } \\
\text { Output WS1 } \\
\text { Output WS2 }\end{array}$ & $\dot{.}$ & $\begin{array}{l}0.470 \\
0.955 \\
1.161\end{array}$ & $\begin{array}{l}0.540 \\
1.074 \\
0.946\end{array}$ & $\begin{array}{l}1.570 \\
1.132 \\
0.985\end{array}$ & $\begin{array}{l}0.890 \\
1.601 \\
1.204\end{array}$ & $\begin{array}{l}0.720 \\
0.799 \\
0.402\end{array}$ & $\begin{array}{l}1.770 \\
3.459 \\
2.747\end{array}$ & $\begin{array}{l}0.99 \\
1.50 \\
1.24\end{array}$ \\
\hline $\begin{array}{l}\text { ANNUAL SUMS } \\
\text { Input C1 } \\
\text { Output WS1 } \\
\text { Output WS2 } \\
\end{array}$ & $\begin{array}{l}\text { S. } \\
\dot{ }\end{array}$ & $\dot{.}$ & $\begin{array}{l}36.370 \\
12.944 \\
10.390 \\
\end{array}$ & $\begin{array}{r}20.990 \\
10.368 \\
8.709 \\
\end{array}$ & $\begin{array}{r}16.080 \\
11.167 \\
9.840 \\
\end{array}$ & $\begin{array}{r}16.150 \\
11.063 \\
9.025 \\
\end{array}$ & $\begin{array}{l}11.730 \\
10.552 \\
10.690 \\
\end{array}$ & $\begin{array}{r}18.05 \\
10.56 \\
8.47 \\
\end{array}$ \\
\hline
\end{tabular}


